\title{
EkoMiasto\#Gospodarka
}

Zrównoważony, inteligentny i partycypacyjny rozwój miasta

pod redakcją

Aleksandry Nowakowskiej

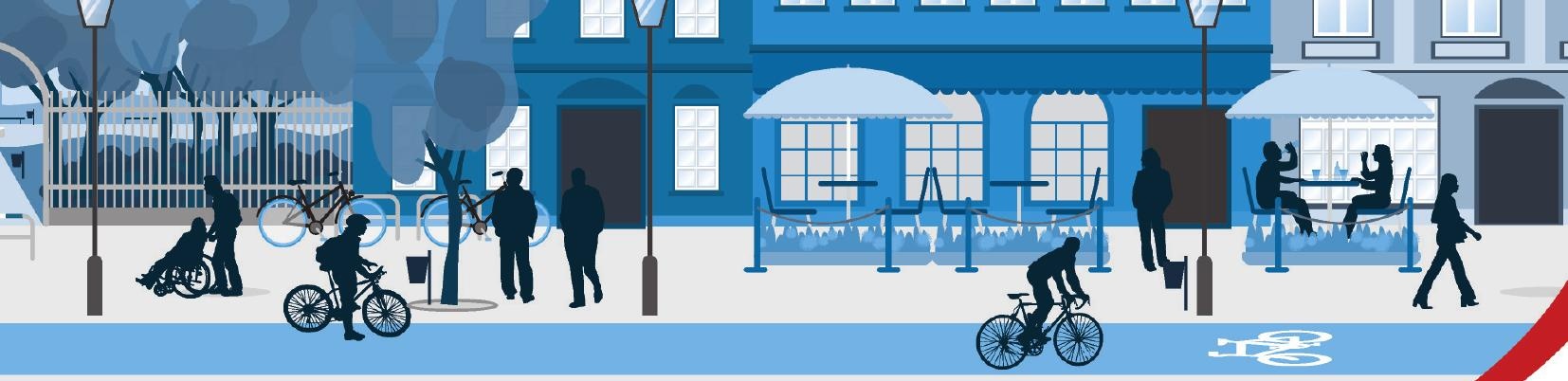


http://dx.doi.org/10.18778/7969-968-1.04

Mariusz E. Sokołowicz* Jakub Zasina**

\section{EKONOMIA MIASTA}

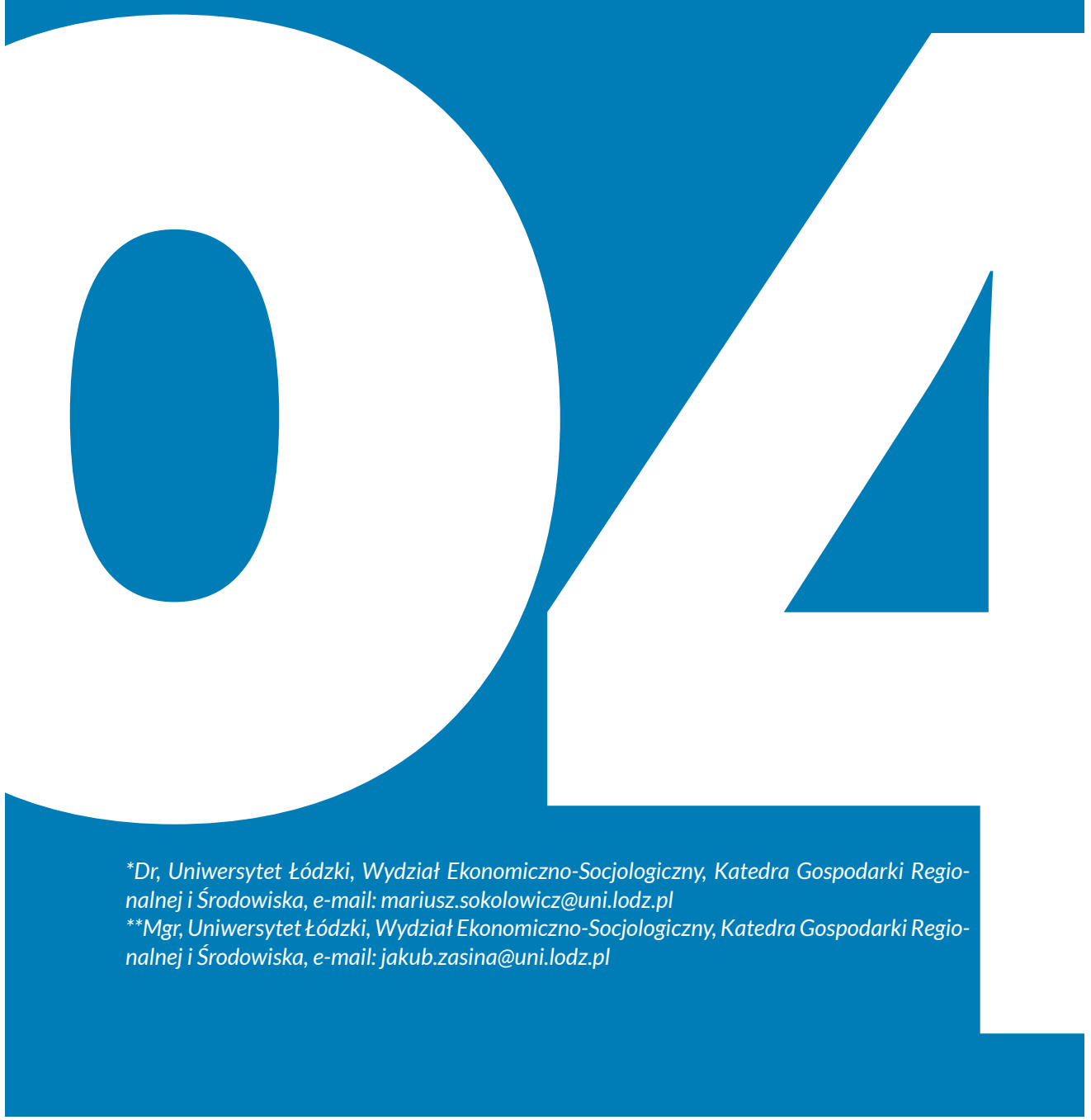




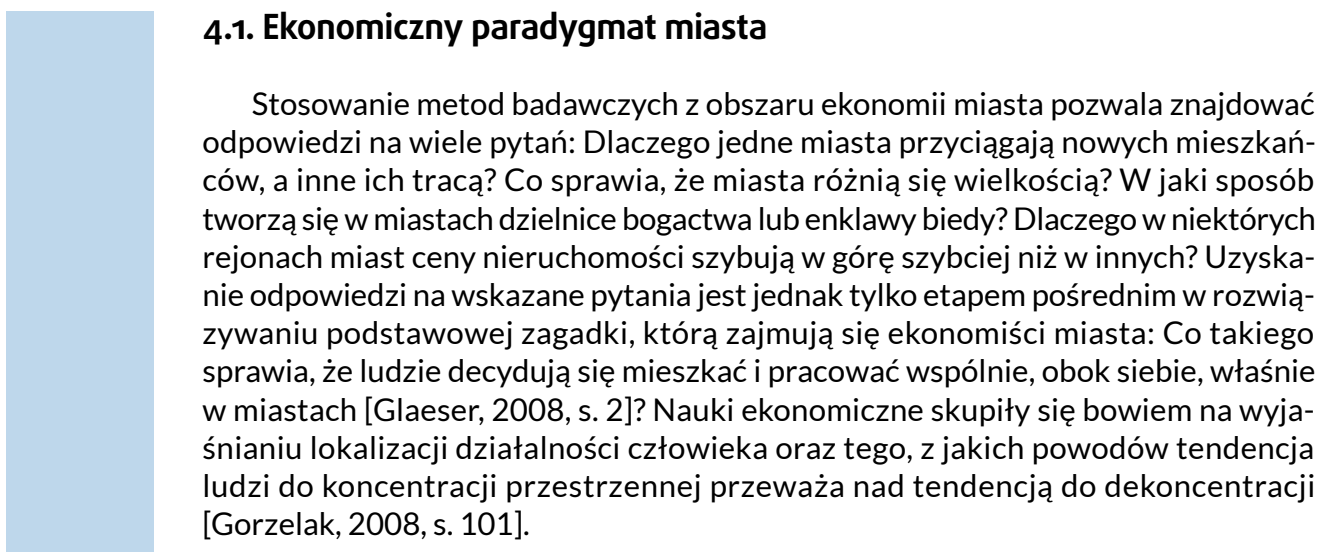

\subsubsection{Miasto jako przedmiot badań ekonomii}

Można pokusić się o stwierdzenie, że procesy gospodarcze były od zarania przede wszystkim procesami zachodzącymi w miastach. Pojęcie rynku, kluczowe dla nauk ekonomicznych, zrodziło się z fizycznego miejsca w przestrzeni, gdzie dokonywano targów. To w miastach koncentrowała się wystarczająco liczna grupa aktorów ekonomicznych, dokonujących między sobą transakcji. Stąd, tworząc pojęcie rynku, ekonomiści najpewniej inspirowali się tym, co mogli obserwować właśnie w przestrzeni miejskiej [Ikeda, 2007]. Mimo to ekonomiści początkowo analizowali współzależności gospodarcze bez uwzględniania czynnika przestrzeni. Innymi słowy, umieli powiedzieć, co, w jakiej ilości i dla kogo produkować, jednak spotykali się z trudnościami, gdy należało wskazać, gdzie tę produkcję prowadzić [Zaucha, 2010a, s. 53]. Analizy ekonomiczne udało się najpierw zdynamizować za sprawą uwzględnienia czynnika czasu, później zaś zainteresowano się przestrzennym wymiarem procesów gospodarczych [Domański, 2006, s. 17]. Relatywnie szybko zróżnicowanie przestrzenne procesów gospodarczych uwzględnili w swych analizach badacze niemieccy [Arnott, 2012, s. 55]. Choć podstawy, na których opiera się współczesna ekonomia miasta, są starsze - a wywodzą się one z obserwacji sposobów zagospodarowania terenów wiejskich - jej początki jako samodzielnej gałęzi ekonomii datuje się na lata 60. XX wieku.

W przeciwieństwie do innych gałęzi ekonomii ekonomię miasta wyodrębnia się w oparciu o kryterium przestrzenne. Subdyscyplina ta różni się zatem od pozostałych ekonomik stosowanych, koncentrujących się na określonych działach gospodarki (np. ekonomika turystyki, ekonomika przemysłu) [Bury et al., 1993, s. 5; Regulski, 1982, s. 13-14]. Warto również zauważyć, że ekonomia miasta cechuje się dwoma płaszczyznami prowadzenia badań. Dzieje się tak, ponieważ analizy podejmowane przez ekonomistów miasta dotyczą zarówno systemu osadniczego jako całości (gdy skupiają się na systemie jednostek osadniczych - w tym miast - i na zależnościach zachodzących pomiędzy tymi jednostkami), jak i na pojedynczych miastach (gdy ekonomiści badają zjawiska zachodzące w ich obrębie) [Regulski, 1982, s. 16].

Można powiedzieć, że współczesna ekonomia miasta wykazuje najsilniejsze powiązania z trzema dyscyplinami szczegółowymi, tj. ekonomiką mieszkalnictwa (housing economics), ekonomiką transportu (transport economics) oraz gospodarką przestrzenną miast (land-use economics). Przy czym tak zdefiniowana ekonomia miasta (urban economics) jest zdecydowanie częściej domeną naukowców z Ame- 
ryki Północnej niż ich kolegów z krajów europejskich, gdyż na Starym Kontynencie wciąż trwalsze pozostają podziały na wskazane trzy ekonomiki szczegółowe [Arnott, 2012, s. 55, 68].

Trzeba jednak zadać sobie podstawowe pytanie o to, dlaczego ekonomia interesuje się miastami. Przede wszystkim dlatego, że nauka ta z definicji zajmuje się ludzkimi potrzebami, a miasta - jako swoista konstrukcja cywilizacyjna - służą zaspokajaniu potrzeb ludzkich (zamieszkanie, praca, bezpieczeństwo, możliwości rozwoju zgodnego z własnymi aspiracjami itp.). Należy przy tym pamiętać, że ekonomia miejska nie ogranicza się jedynie do takich zagadnień, jak finanse miasta, transakcje na rynku nieruchomości czy efektywność inwestycji miejskich. Elementy te są ważne i stanowią przedmiot zainteresowań tej dziedziny wiedzy, trzeba je jednak rozpatrywać w znacznie szerszym kontekście. Dlatego za punkt wyjścia przy określaniu zakresu badawczego ekonomii miejskiej należy przyjąć szerszą paletę podstawowych pojęć i kategorii ekonomicznych. Należą do nich przede wszystkim:

1) potrzeby wraz z założeniem ich nieograniczoności;

2) zasoby wraz z założeniem ich ograniczoności;

3) przedsiębiorstwa, stojące przed dylematem optymalnej lokalizacji oraz dostępności surowców, zasobów pracy, kooperantów i rynków zbytu;

4) gospodarstwa domowe, dążące do maksymalizacji użyteczności w konsumpcji oferowanych w miastach dóbr i usług;

5) wymiana towarowo-pieniężna i jej skutki dla formowania się miast i ich hierarchii.

6) efektywność procesów gospodarczych w miastach.

7) ekonomia sektora publicznego w miastach.

Wykorzystując powyższe kategorie, ekonomia miasta zajmuje się zatem wyjaśnianiem zarówno uniwersalnych przyczyn powstania i rozwoju miast, jak i przyczyn występujących między nimi różnic. Podsumowując, ekonomia miasta stanowi dyscyplinę z kręgu nauk ekonomicznych badającą procesy i prawidłowości ekonomiczne związane z rozwojem i funkcjonowaniem miast oraz mającą na celu ustalenie skutecznych narzędzi polityki gospodarczej w tej dziedzinie [Regulski, 1982, s. 14; Bury et al., 1993, s. 5]. Jako najważniejsze obszary zainteresowań ekonomii miasta wskazuje się natomiast:

1) wpływ decyzji ekonomicznych gospodarstw domowych i przedsiębiorstw na powstawanie i rozwój miast;

2) zróżnicowanie wartości terenów w mieście w zależności od popytu i podaży na grunty miejskie i sposób ich wykorzystania;

3) konsumpcję w mieście (handel, usługi) i sposób zaspokajania potrzeb mieszkańców miast;

4) ekonomikę przemieszczania się w mieście i analizę funkcjonowania miejskich systemów transportowych.

5) dobra publiczne i sektor publiczny w mieście (usługi komunalne, ochrona środowiska, walka z przestępczością, miejski porządek instytucjonalny itp.);

6) problemy optymalizacji i efektywności działań w mieście (polityka miejska i zarządzanie miastem).

Warto zauważyć, że choć analiza powyższych zagadnień ma podłoże ekonomiczne, ich złożoność i różnorodność wymagają także czerpania wiedzy z innych nauk. W ekonomii miejskiej kładzie się bowiem nacisk zarówno na aspekty ekonomiczne, jak i społeczne, przestrzenne, środowiskowe oraz techniczne. Należy zatem traktować tę dziedzinę wiedzy jako interdyscyplinarną i wciąż ewoluującą, czerpiącą z dorobku intelektualnego ekonomii, socjologii miasta, antropologii, architektury i urbanistyki, geografii urbanistycznej, nauk o ochronie środowiska, inżynierii miejskiej czy politologii. 


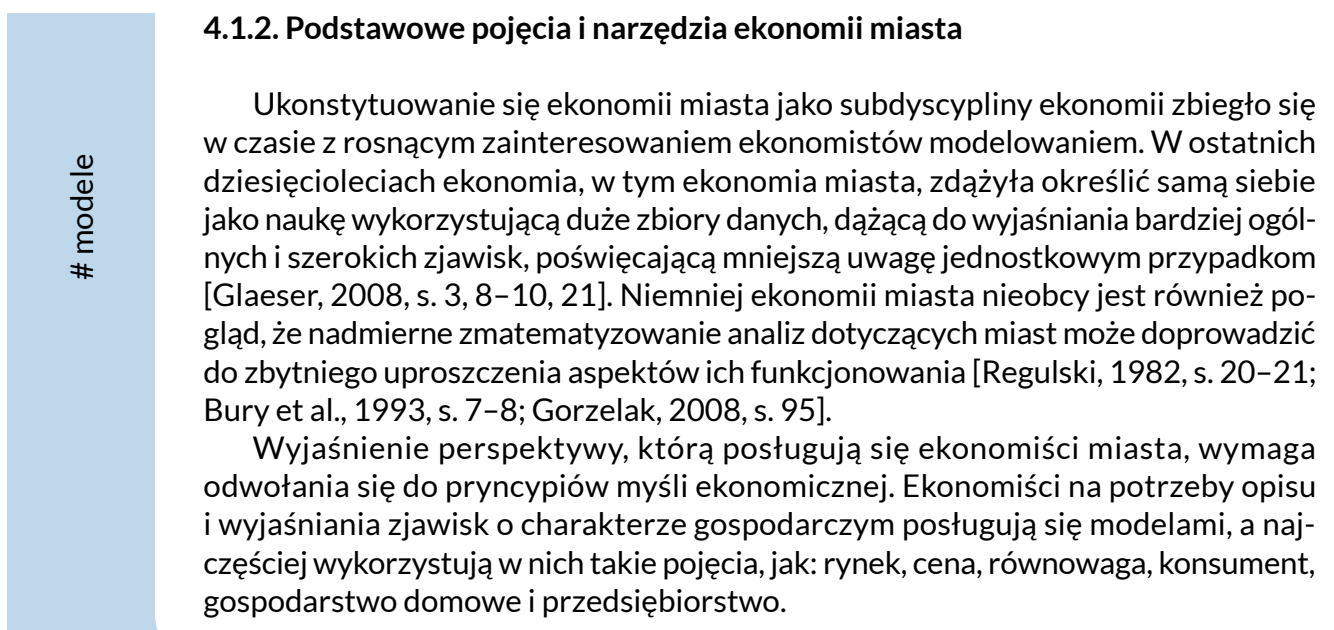

\section{Modele w ekonomii miasta}

Modele są uproszczonymi obrazami rzeczywistości. Ponieważ rzeczywistość ta jest złożona, ekonomiści dążą do redukcji liczby zmiennych uwzględnianych w modelach po to, by zwrócić uwagę na kluczowe spośród licznych zależności między określonymi zjawiskami. Jednocześnie przy opracowywaniu modeli ekonomiści przyjmują restrykcyjne założenia dotyczące funkcjonowania gospodarki, aby zależności te mogły być w modelach właściwie odwzorowane. Modele tłumaczą, jak zachowuje się gospodarka lub jak zachowują się na rynku tacy aktorzy, jak przedsiębiorstwa i gospodarstwa domowe, a ich wykorzystywanie ma dawać wskazówki dla prowadzenia polityki gospodarczej. Modele przyjmują postać równań matematycznych, znajdują też graficzne odwzorowanie na wykresach i schematach. Warto jednak zauważyć, że w odróżnieniu do wielu innych subdyscyplin ekonomii w modelach wykorzystywanych przez ekonomię miasta uwzględnia się czynnik przestrzeni. Poniżej zawarto przykłady tego, jak ekonomiści „kadrują" przestrzeń swoimi modelami oraz jak przestrzeń ta wygląda w rzeczywistości.

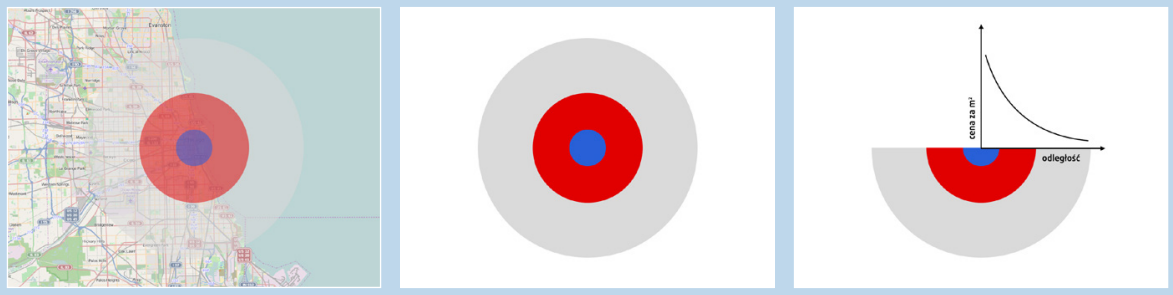

Źródto: opracowanie wlasne z. wykorzystaniem podkładu OpenStreetMaps.
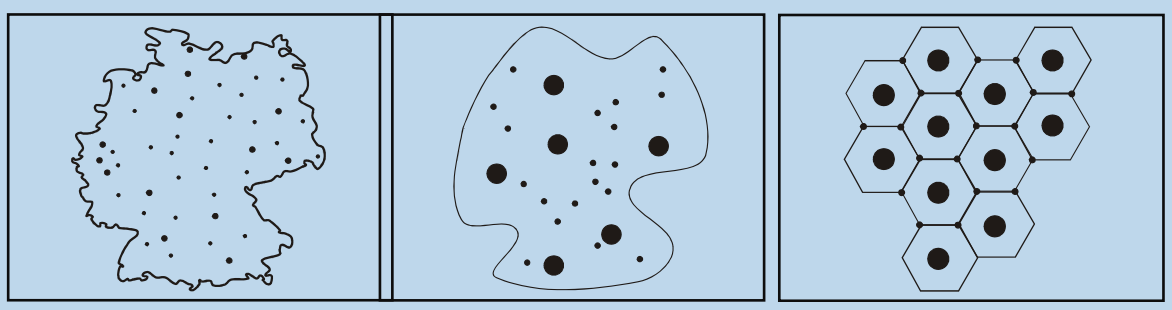

Źródto: opracowanie własne. 
Ekonomiści uważają rynek za relatywnie sprawny mechanizm regulujący procesy gospodarcze [Arnott, 2012, s. 51], choć dostrzegają jego ułomności. Istotną zaletą rynku jest to, że wiąże on ze sobą miliony konsumentów z milionami producentów. Tym samym rynek sprawia, że decyzje konsumentów o nabyciu określonych dóbr stają się bodźcem dla wytwórców, by określone dobra im dostarczać. Z tego powodu upowszechniło się sformułowanie o tzw. niewidzialnej ręce rynku. Ekonomiści zakładają też, że pojedynczy konsumenci, gospodarstwa domowe i przedsiębiorstwa reagują na bodźce (nie tylko finansowe), co skłania ich do podejmowania określonej aktywności (np. zakupu dobra lub zmiany lokalizacji w przestrzeni).

Podstawowym nośnikiem informacji na rynku jest cena, która z jednej strony oddziałuje na zachowania konsumentów i producentów, a z drugiej sama jest przez te zachowania kształtowana. Dzięki cenie konsumenci są w stanie określić, jaką ilość danego dobra mogą konsumować. $Z$ kolei dla producentów jest ona wskazówką, czy dane dobro opłaca im się wytwarzać. Rynek dąży do osiągnięcia sytuacji równowagi, w której przy określonej cenie uda się pogodzić dążenie konsumentów do maksymalizacji satysfakcji oraz dążenie producentów do maksymalizacji zysku.

Nie jest przypadkiem to, że ekonomia miasta posługuje się przede wszystkim kategorią gospodarstw domowych, a nie kategorią konsumentów. Dzieje się tak, ponieważ jednym z filarów analiz prowadzonych przez ekonomistów miasta są wybory ludzi w zakresie miejsca zamieszkania, a ludzie wciąż częściej zamieszkują wspólnie niż w pojedynkę. Stąd ekonomia miasta - częściej niż pozostałe subdyscypliny ekonomii - wykorzystuje różnicę terminologiczną między konsumentem (utożsamianym z pojedynczą osobą) a gospodarstwem domowym (na które składa się zazwyczaj większa liczba osób, wspólnie zamieszkujących i dzielących między sobą dochody) ${ }^{1}$. Zakłada się, że gospodarstwa domowe dążą do maksymalizacji własnej satysfakcji (przy czym ekonomiści używają głównie pojęcia użyteczności). Z kolei przedsiębiorstwo jest jednostką, która prowadzi działalność gospodarczą polegającą na zaspokajaniu potrzeb konsumentów i gospodarstw domowych. Przyjmuje się, że przedsiębiorstwo dąży w swej działalności przede wszystkim do maksymalizacji zysku.

\subsection{Logika i dynamika przekształceń struktur miejskich}

Ekonomiczny punkt widzenia sugeruje, że miasta są przestrzenną emanacją koncentracji procesów gospodarczych [Storper, Manville, 2006]. Definiując miasto z perspektywy ekonomicznej, zakłada się, że stanowi ono efekt zachowań i decyzji przestrzennych gospodarstw domowych i przedsiębiorstw, stymulowanych lub ograniczanych przez uwarunkowania wynikające z funkcjonowania sektora publicznego [Goodall, 1972, s. 1]. Decyzje te wynikają przy tym z potrzeb i preferencji wymienionych podmiotów. Proces podejmowania decyzji przez tych aktorów raz może prowadzić do stymulacji rozwoju miasta, a innym razem potrafi go hamować i z tego powodu nigdy nie można go uznać za zakończony. Stąd ekonomiczna perspektywa wskazuje, by uznawać miasta za wiecznie nieukończony organizm, podlegający ciągłemu przekształcaniu.

\footnotetext{
${ }^{1}$ Sytuacją, w której za równoznaczne można uznać kategorię „konsumenta” i kategorię „gospodarstwa domowego", jest przypadek jednoosobowego gospodarstwa domowego, czyli gospodarstwa tworzonego tylko przez jedną osobę. Są nimi zazwyczaj single, wdowy/wdowcy lub osoby rozwiedzione. W ostatnich dekadach liczba jednoosobowych gospodarstw domowych na świecie istotnie wzrosła, a wzrost ten dotyczył głównie miast. Udział jednoosobowych gospodarstw domowych w strukturze gospodarstw ogółem w największych europejskich miastach przekracza dziś nawet 60\% [Zasina, 2015].
} 


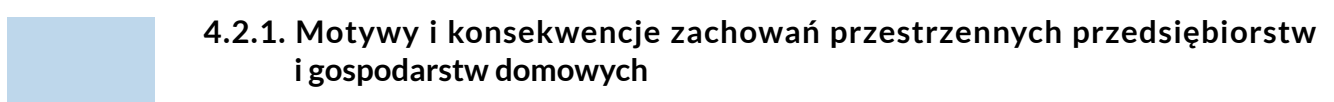

Jednym z głównych nurtów poszukiwań ekonomii miasta jest próba zrozumienia decyzji lokalizacyjnych gospodarstw domowych oraz przedsiębiorstw, zarówno w zakresie wyboru danego miasta spośród wielu innych, jak i wyboru określonego rejonu w obrębie miasta. Gospodarstwa domowe i przedsiębiorstwa dążą do zajęcia najlepszej, z ich punktu widzenia, lokalizacji w przestrzeni [Regulski, 1982, s. 18], czyli lokalizacji, w której najlepiej będą mogły zaspokajać swoje potrzeby (gospodarstwa domowe) lub w której będą mogły najlepiej prowadzić działalność gospodarczą (przedsiębiorstwa). Aczkolwiek natura decyzji lokalizacyjnych obu tych aktorów różni się od siebie, ponieważ różne są cele, którymi się kierują: przedsiębiorstwo dąży do maksymalizacji zysku, gospodarstwo domowe zaś skupia się na maksymalizacji własnej użyteczności (satysfakcji).

Decyzje lokalizacyjne mają swój wymiar ekonomiczny, ponieważ bez względu na to, czy dotyczą one wyboru miejsca zamieszkania, czy też wyboru miejsca prowadzenia działalności gospodarczej, decyzje te są podstawowym i jednym z najbardziej oczywistych sposobów wydatkowania środków pieniężnych [Glaeser et al., 2001; Gorzelak, 2008, s. 90]. Co więcej, wybór lokalizacji w przestrzeni należy uznać za najbardziej podstawowy wybór, przed którym staje i przedsiębiorstwo, i gospodarstwo domowe, jako że wybór ten odnosi się bezpośrednio do ich potrzeb, a większość późniejszych decyzji obu aktorów jest podejmowana w nawiązaniu do konkretnego punktu w przestrzeni [van den Berg et al., 1982, s. 8-9].

Większość nurtów teoretycznych uwzględniających przestrzeń w procesach gospodarczych za podstawowe przyczyny koncentracji przedsiębiorstw i gospodarstw domowych uznaje korzyści aglomeracji. Stanowią one formę korzyści zewnętrznych, wynikających ze skupienia na małym obszarze ludności, zabudowy, produkcji, usług, działalności handlowej etc. W ujęciu mikroekonomicznym korzyści aglomeracji są zatem czynnikiem wpływającym na poziom użyteczności przedsiębiorstw i gospodarstw domowych, choć podmioty te, jako odbiorcy efektów zewnętrznych, nie mają wpływu na ich siłę.

Rysunek 4.2. Klasyfikacja przyczyn koncentracji działalności gospodarczej - korzyści aglomeracji

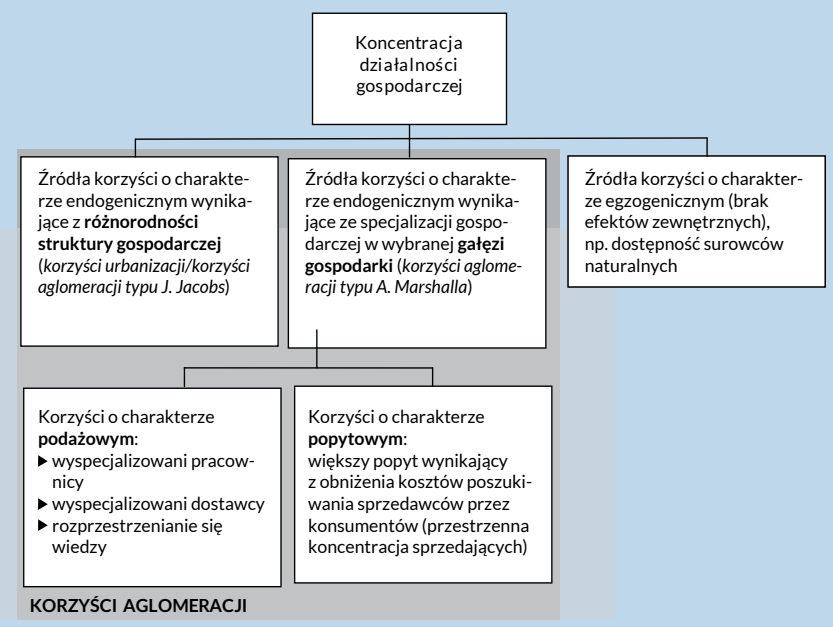

Źródto: McCann, Folta, 2008, s. 534. 
Koncentracja przedsiębiorstw i gospodarstw domowych na relatywnie niewielkiej przestrzeni prowadzi do sytuacji, w której jej użytkownicy uzyskują dostęp do różnorodnych pożytków, prowadzących np. do obniżenia jednostkowych kosztów produkcji, powiększenia rynku zbytu, możliwości funkcjonowania na lepiej rozwiniętym rynku pracy, zapewnienia różnorodności wyborów konsumenckich czy też korzystania z dobrodziejstw korzyści skali w użytkowaniu infrastruktury przez relatywnie dużą liczbę użytkowników. W ujęciu makroekonomicznym korzyści aglomeracji stanowią zatem najbardziej fundamentalną formę wyjaśniania przyczyn koncentracji działalności gospodarczej w przestrzeni. Ekonomiczną przyczyną istnienia dużych skupisk ludności i działalności gospodarczej jest niewątpliwie to, że działalność w nich zapewnia większą produktywność i rosnące zyski [Lucas, 1993, s. 251-272; Sokołowicz, 2015, s. 47].

Przyczyną, dla której gospodarstwa domowe decydują się na zmianę lokalizacji w przestrzeni, jest zazwyczaj ich przekonanie, że w innym miejscu będą mogły lepiej zaspokajać swoje potrzeby (np. przeniosą się do bardziej komfortowego mieszkania, uzyskają dostęp do lepszej pracy albo do pożądanych udogodnień - np. parku, kawiarni, sklepów itd.). Dzieje się tak, ponieważ gospodarstwa domowe oceniają swoje bieżące położenie na tle własnych doświadczeń z przeszłości, a także za sprawą porównywania się z innymi gospodarstwami [Regulski, 1982, s. 58-64; Bury et al., 1993, s. 33-35]. Co więcej, ludzie często nie migrują dlatego, że w danym miejscu jest im źle, ale dlatego, że są przekonani, iż w innym miejscu mogą żyć lepiej [Kuciński, 2004]. Poszczególne gospodarstwa domowe różnią się jednak od siebie preferencjami w zakresie wyboru miejsca zamieszkania, ponieważ każdemu gospodarstwu może zależeć na innej wiązce udogodnień, których oczekuje od lokalizacji w przestrzeni. Stąd ekonomiści miasta zakładają, że nikt inny nie jest w stanie wyrazić swoich preferencji lepiej niż samo gospodarstwo domowe. Ekonomiczny punkt widzenia sugeruje zatem, że wszystkie gospodarstwa domowe "mają rację", samodzielnie wskazując swoje upragnione miejsce zamieszkania. Rację ma zatem zarówno to gospodarstwo, które chce zamieszkiwać w centrum miasta, jak i to gospodarstwo, które pragnie mieszkać na przedmieściach, ponieważ oba te gospodarstwa wiedzą najlepiej, co przyniesie im większą satysfakcję i gdzie lepiej zaspokoją własne potrzeby [Klaassen, 1988, s. 68]².

Gospodarstwa domowe w Europie relatywnie rzadko decydują się zmienić lokalizację z jednego miasta na drugie. Zdecydowanie bardziej mobilne są w tym względzie gospodarstwa amerykańskie. Przyjmuje się, że jednym z najważniejszych powodów zmiany lokalizacji gospodarstwa domowego pomiędzy miastami jest chęć uzyskania lepszego miejsca pracy lub chęć poprawienia własnych możliwości konsumpcyjnych. Tym samym rozkład przestrzenny gospodarstw domowych pomiędzy miastami będzie odpowiadać szansom, jakie miasta te stwarzają swoim mieszkańcom zarówno w zakresie zarobkowania, jak i wydatkowania pieniędzy na cele konsumpcyjne. Większość gospodarstw domowych bierze pod uwagę obie kategorie, natomiast część z nich skupia się wyłącznie na aspekcie konsumpcyjnym - przypadkiem tym są gospodarstwa domowe wyłączone z rynku pracy (np. gospodarstwa prowadzone przez emerytów) [Goodall, 1972, s. 148].

Częściej gospodarstwa domowe mają okazję zmienić miejsce zamieszkania w obrębie miasta. W tym przypadku można wyróżnić trzy główne kategorie atrybutów (cech) danej lokalizacji, które są oceniane przez gospodarstwo domowe

\footnotetext{
${ }^{2}$ Inną sprawą jest to, na ile preferencje i działalność jednego gospodarstwa domowego oddziałują (pozytywnie lub negatywnie) na pozostałe gospodarstwa domowe oraz czy oddziaływanie to powinno być w jakiś sposób regulowane. Temat tzw. efektów zewnętrznych podjęto w ostatniej części niniejszego rozdziału.
} 
i które ostatecznie przekładają się na jego decyzję lokalizacyjną. Są nimi [za: Goodall, 1972, s. 151-152]:

1. Cechy mieszkania/domu.

Jedne chcą zamieszkiwać w domu jednorodzinnym, inne w lokalach w budynkach wielorodzinnych (np. w kamienicach, blokach). Każdy ze wskazanych typów zabudowy może zaoferować inne warunki bytowe.

2. Cechy rejonu.

Każdy rejon miasta wyposażony jest w określone udogodnienia, przy czym rejony mogą być silnie zróżnicowane pod względem oferowanych udogodnień. Gospodarstwo domowe będzie poszukiwać rejonu o ofercie udogodnień najbliższej jego potrzebom.

3. Związki przestrzenne lokalizacji z otoczeniem.

Najczęściej wskazuje się na związek pomiędzy miejscem zamieszkania a miejscem pracy. Przyjmuje się, że gospodarstwo domowe lokalizuje się relatywnie blisko miejsca pracy, aby codzienne podróże między pracą a domem nie były zbyt uciążliwe.

Udogodnienia miejskie a atrakcyjność rejonu zamieszkania w mieście

Teorie lokalizacji próbują odpowiedzieć na pytanie, dlaczego ludzie zamieszkują właśnie w tej, a nie w wielu innych lokalizacjach. Istnieją tysiące powodów, dla których określona lokalizacja w przestrzeni jest przez gospodarstwa domowe oceniana jako atrakcyjna. Powody za sprawą których życie w danym miejscu jest przyjemne, komfortowe lub łatwe w ekonomii miasta obejmuje się kategorią udogodnień3 (amenities). Udogodnienia są zatem dobrami, z których część jest dziełami natury (np. krajobraz przyrodniczy, flora, klimat), a większość stanowi efekt działalności człowieka (np. parki, historyczne budynki, restauracje, teatry, szkoły, infrastruktura sportowa itp.). Warto zauważyć, że udogodnienia różnią się od dóbr powszechnie dostępnych przede wszystkim tym, że można z nich skorzystać tylko w określonej lokalizacji. Z tego powodu określa się je mianem immobilnych. Przykładowo nie można przenieść pięknego widoku na górski masyw $z$ jednego miejsca w drugie, ponieważ jest on trwale związany z przestrzenią. Tym samym jeśli gospodarstwo domowe chciałoby skorzystać z udogodnienia, z którego w danej chwili skorzystać nie może, lub chciałoby zastąpić obecnie użytkowane udogodnienie takim, które zwiększyłoby jego satysfakcję, konieczna okazałaby się zmiana lokalizacji na oferującą pożądane udogodnienia [Diamond, Tolley, 1982, s. 3-9]. Odległość, jaką trzeba pokonać, by skorzystać z danego udogodnienia, jest istotna, ponieważ wiąże się ona z poniesieniem kosztów dojazdu, a także wysiłkiem i czasem, które należy temu poświęcić. Zatem im odległość ta staje się większa, tym satysfakcja czerpana z korzystania z określonego udogodnienia maleje. Podsumowując, zakres i jakość oferty lokalnych udogodnień są bodźcem dla gospodarstw domowych do podejmowania decyzji o pozostaniu w określonej lokalizacji bądź decyzji o zmianie tej lokalizacji, mając na myśli zarówno całe miasto, jak i jego rejon.

Źródto: opracowanie własne.

Gospodarstwa domowe we współczesnych miastach stanowią heterogeniczny (zróżnicowany) zbiór, a zmiany w ich liczbie i strukturze zachodzą w ostatnich dekadach bardzo szybko [Tscharaktschiew, Hirte, 2010]. Stąd wśród czynników różnicujących decyzje lokalizacyjne gospodarstw domowych najczęściej odwołuje się do właściwości samych gospodarstw: 
1. Dochód gospodarstwa domowego.

W zależności od wysokości swojego dochodu gospodarstwa domowe różnią się preferencjami lokalizacyjnymi. Wysokość dochodu przekłada się na wymagania wobec budynku, najbliższej okolicy czy pożądanej odległości do miejsca pracy.

2. Wielkość i wiek gospodarstwa domowego.

Wybory lokalizacyjne gospodarstw domowych są wypadkową preferencji osób, które składają się na dane gospodarstwo. Inne preferencje lokalizacyjne będą miały rodziny z dziećmi, inne pary bezdzietne, a jeszcze inne osoby mieszkające samodzielnie (np. młodzi single lub osoby w podeszłym wieku).

W przypadku przedsiębiorstw jako aktorów ekonomicznej „gry o miasto” ich wybory lokalizacyjne można rozpatrywać w kategoriach czynników lokalizacji działalności gospodarczej. Dorobek teorii lokalizacji jest bardzo obszerny, a jego początki sięgają połowy XIX wieku. Na przestrzeni lat dostrzegalne jest przy tym ciągłe poszerzanie katalogu czynników decydujących o lokalizacji przedsiębiorstw w przestrzeni. W pierwszych teoriach lokalizacji koncentrowano się przede wszystkim na optymalizacji modeli lokalizacji inwestycji, uwzględniających dość ograniczony katalog czynników (dostęp do surowców naturalnych, rynków zbytu, koszty transportu). Z czasem ten nurt teoretyczny uzupełniano o inne elementy, takie jak: czynnik aglomeracji i związane z nim efekty zewnętrzne i efekty skali produkcji, czynnik polityczno-administracyjny itd.

Wszelkie czynności podejmowane przez podmioty gospodarujące zachodzą w określonym miejscu przestrzeni, a zatem są zlokalizowane. Podjęcie decyzji o wyborze miejsca lokalizacji ${ }^{4}$ stanowi jedną z podstawowych decyzji podejmowanych przez każde przedsiębiorstwo w procesie organizacji produkcji. Pojęcie czynników lokalizacji jako pierwszy wprowadził do teorii ekonomii A. Weber [1909], wiążąc je z określoną korzyścią występującą wówczas, gdy działalność gospodarcza jest zlokalizowana w określonym punkcie lub obszarze. Dalszy postęp badań nad istotą i ewolucją czynników lokalizacji rozszerzył ich listę o rynek zbytu oraz bazę surowcową i energetyczną jako kolejne istotne elementy decydujące o lokalizacji działalności gospodarczej [Godlewska, 2001, s. 14]. Ze względu na wzrost znaczenia przemysłu w gospodarce oraz z powodu rosnącej roli funkcji ekonomicznych państwa listę czynników lokalizacji uzupełnił także element strategiczny i polityczny. Zadecydował on m.in. o rozmieszczaniu działalności o znaczeniu militarnym czy też o lokalizacji zakładów przemysłu ciężkiego. Coraz bardziej wszechobecne zainteresowanie zagadnieniami z zakresu ekologii oraz rosnący problem zagrożenia środowiska naturalnego uzupełniły katalog czynników lokalizacji o kwestie środowiskowe. Dzisiaj teoria lokalizacji działalności gospodarczej poszerzana jest też o czynniki z zakresu takich nauk, jak psychologia czy socjologia, uwzględniając np. problematykę subiektywnego wizerunku danego miejsca z punktu widzenia jego atrakcyjności lokalizacyjnej [Godlewska, 2001, s. 15].

\footnotetext{
${ }^{3}$ Anglosaska literatura posługuje się pojęciem udogodnień miejskich (urban amenities) już od lat 30. XX wieku. Stosunkowo często pojęcie udogodnień miejskich pojawia się w literaturze przedmiotu w kontekście miast poprzemysłowych, w których na znaczeniu zyskuje zagadnienie jakości życia [zob. Glaeser et al., 2001]. W języku polskim koncepcja udogodnień miejskich nie doczekała się do tej pory wystarczającego rozgłosu, który doprowadziłby do wypracowania i upowszechnienia polskiego tłumaczenia tego terminu. Stąd autorzy rozdziału posługują się własną propozycją. Wcześniejsza literatura polska z obszaru ekonomii miasta posługiwała się pojęciami „urządzeń”, „obiektów” oraz „usług” przy omawianiu podobnych zagadnień.

${ }^{4}$ Termin „lokalizacja” pochodzi od łacińskiego słowa locare - umieścić.
} 
Badania nad lokalizacją działalności gospodarczej pozwalają stwierdzić, że czynniki lokalizacji nie są ani zbiorem stałym, ani zamkniętym. Dostrzec można ponadto, że obok tradycyjnych i jednoznacznie mierzalnych czynników (tzw. twardych czynników lokalizacji) znaczenia nabierają także czynniki „miękkie”. Obecnie takie kryteria, jak dostępność surowców naturalnych, zasoby kapitału materialnego, koszty pracy i transportu, często uzupełniane są lub nawet zastępowane przez takie czynniki, jak: zasoby naukowe i badawcze miasta, wysoko wykwalifikowana kadra, profesjonalna administracja publiczna, wysoka jakość infrastruktury technicznej, wysoki standard warunków życia, obecność instytucji wspierania biznesu, wartości społeczne, zasobny rynek konsumencki itd. [por. Grosse, 2002].

Bardzo istotne znaczenie z punktu widzenia atrakcyjności inwestycyjnej ma dzisiaj szeroko pojęte otoczenie działalności gospodarczej. Obecność instytucji i firm

Tabela 4.1. „Twarde” i „miękkie” czynniki lokalizacji

\begin{tabular}{|c|c|c|}
\hline Obszary & „Twarde” czynniki lokalizacji & „Miękkie” czynniki lokalizacji \\
\hline Rynek pracy & $\begin{array}{l}\text { podaż pracy } \\
\text { poziom wynagrodzeń }\end{array}$ & $\begin{array}{l}\text { jakość działania administra- } \\
\text { cji rynku pracy } \\
\text { elastyczność rynków pracy } \\
\text { możliwości kształcenia } \\
\text { pracowników }\end{array}$ \\
\hline $\begin{array}{l}\text { Infrastruktura działalności } \\
\text { gospodarczej }\end{array}$ & $\begin{array}{l}\text { podaż gruntów } \\
\text { podaż powierzchni biuro- } \\
\text { wej i produkcyjnej } \\
\text { długość i gęstość połączeń } \\
\text { transportowych } \\
\text { poziom wyposażenia } \\
\text { w urządzenia infrastruktury } \\
\text { technicznej }\end{array}$ & $\begin{array}{l}\text { wizerunek gospodarczy } \\
\text { miast i regionów } \\
\text { sprawność systemów trans- } \\
\text { portowych } \\
\text { jakość przestrzeni publicz- } \\
\text { nych } \\
\text { sprawność funkcjonowania } \\
\text { infrastruktury technicznej }\end{array}$ \\
\hline Koszty i korzyści działalności & $\begin{array}{l}\text { ceny nieruchomości } \\
\text { poziom podatków i opłat } \\
\text { ceny mediów } \\
\text { poziom ulg podatkowych } \\
\text { dla przedsiębiorstw, wiel- } \\
\text { kość wsparcia finansowego } \\
\text { dla działalności gospo- } \\
\text { darczej }\end{array}$ & $\begin{array}{l}\text { różnice w pensjach i upo- } \\
\text { sażeniach między różnymi } \\
\text { lokalizacjami }\end{array}$ \\
\hline Położenie miejsca lokalizacji & $\begin{array}{l}\text { dostępność ważnych okrę- } \\
\text { gów gospodarczych } \\
\text { i rynków zbytu }\end{array}$ & $\begin{array}{l}\text { jakość położenia geogra- } \\
\text { ficznego } \\
\text { położenie geopolityczne }\end{array}$ \\
\hline Jakość środowiska & $\begin{array}{l}\text { poziomy zanieczyszczeń } \\
\text { elementów środowiska (po- } \\
\text { wietrza, wody, gleby itd.) }\end{array}$ & $\begin{array}{l}\text { jakość środowiska z punktu } \\
\text { widzenia zamieszkania } \\
\text { i wypoczynku } \\
\text { dostępność terenów zielo- } \\
\text { nych i obszarów chronio- } \\
\text { nych przyrodniczo } \\
\text { i krajobrazowo } \\
\text { klimat, pogoda } \\
\text { jakość wody itp. }\end{array}$ \\
\hline
\end{tabular}

Źródto: opracowanie własne na podstawie Dziemianowicz, 1997, s. 18-19. 
świadczących tzw. usługi okołobiznesowe zapewnia bowiem możliwość skorzystania z ofert konsultantów oraz dostęp do potrzebnych informacji na temat rynków czy technologii. Nie bez znaczenia dla obiegu informacji i motywowania przedsiębiorstw do działania ma sam fakt zgrupowania wielu firm w jednej przestrzeni, generujący efekty zewnętrzne i efekt synergii. Kolejnym elementem sprzyjającym klimatowi biznesowemu jest obecność instytucji finansowych, w tym szczególnie instytucji zapewniających dostęp do kapitału ryzyka, kluczowej formy finansowania inwestycji innowacyjnych. Wreszcie odpowiednie nastawienie do sfery biznesu władz krajowych i samorządowych, aktywna polityka lokalna wspomagająca i koordynująca funkcjonowanie przedsiębiorstw oraz sprawność administracyjna także stanowią istotny czynnik lokalizacji.

\subsubsection{Ekonomia miasta z perspektywy głównych modeli i koncepcji}

Na gruncie nauk ekonomicznych w ciągu ostatnich 200 lat wypracowano szereg teorii i modeli, które służą wyjaśnianiu nie tylko procesów powstawania miast oraz sił decydujących o kształtowaniu się całych hierarchii osadniczych, lecz także procesów decydujących o zróżnicowaniu sposobów zagospodarowania przestrzennego wewnątrz miast. Do najważniejszych i najbardziej podstawowych koncepcji zalicza się:

1. Modele renty gruntowej i budowlanej, wyjaśniające mechanizm różnicowania wartości terenów w mieście oraz przestrzenną alokację funkcji miejskich (mieszkań, przemysłu, usług, handlu itd.).

2. Koncepcję bazy ekonomicznej pozwalającej zidentyfikować sektory gospodarcze decydujące o rozwoju poszczególnych miast oraz klasyfikować specjalizację funkcjonalną ośrodków miejskich.

3. Modele kształtowania się hierarchii przestrzennej i układów osadniczych wyjaśniające, dlaczego miasta różnią się między sobą wielkością i potencjałem gospodarczym oraz w jaki sposób tworzą one układy osadnicze.

4. Modele polaryzacyjne identyfikujące zarówno przyczyny, jak i skutki rozwoju miast, które dominują w strukturach osadniczych poszczególnych krajów, a także w skali kontynentu i świata.

5. Koncepcje rozwoju endogenicznego wskazujące, jakie wewnętrzne przyczyny mogą decydować o rozwoju miast, które dotychczas nie miały istotnego znaczenia w hierarchii osadniczej.

Historycznie pierwszą koncepcją ekonomiczną poświęconą sposobom wyjaśniania koncentracji działalności gospodarczej było opracowanie niemieckiego ekonomisty J.H. von Thünena [1826]. Analizował on zjawisko różnicowania się wartości terenów użytkowanych rolniczo, a zlokalizowanych wokół miasta będącego rynkiem zbytu towarów rolnych. W swych badaniach doszedł do wniosku, że na kształtowanie się struktury osadniczej wpływają dwa kluczowe czynniki, tj. odległość od rynku zbytu (determinująca koszty transportu) oraz urodzajność ziemi (przekładająca się na wydajność produkcji rolnej). Model ten, badający zróżnicowanie dochodu i wartości ziemi jako czynnika produkcji (czyli tzw. renty gruntowej), pozwolił wskazać, że wartość terenów stanowi wypadkową gry popytu i podaży na ziemię jako czynnik produkcji. O wielkości popytu na grunty decydują przy tym głównie wspominana odległość i urodzajność ziemi. Tym samym renta gruntowa (czyli możliwy do uzyskania dochód z ziemi) jest funkcją odległości działki gruntu od miejsca zbytu wytwarzanych na niej dóbr i wydajności realizowanej na niej produkcji. W miejscu gdzie popyt jest najwyższy, obserwuje się ich najwyższe ceny, malejące wraz z oddalaniem się od miasta będącego rynkiem zbytu. Model renty gruntowej wyjaśnił w ten 
sposób przyczyny zróżnicowania sposobów wykorzystania gruntów według zasady, że najdroższa ziemia zajmowania jest przez rodzaje działalności rolnej gwarantujące dochody na tyle wysokie, że pozwalają one pokryć koszty jej dzierżawy lub zakupu. Natomiast wraz z oddalaniem się od rynku zbytu maleją ceny nieruchomości rolnych i obserwuje się coraz mniej dochodowe typy upraw.

Przeniesieniem logiki modelu von Thünena na warunki miejskie oraz funkcję mieszkaniową jest model miasta W. Alonso. Model ten dotyczy odizolowanego z otoczenia miasta monocentrycznego (tj. posiadającego tylko jedno centrum) i wyjaśnia lokalizację gospodarstw domowych w obrębie miasta. Tłumaczy on, jak kształtują się ceny mieszkań w mieście w zależności od ich dystansu do centrum miasta. Gospodarstwa domowe stawiane są w nim przed wyborem, czy wydatkować więcej pieniędzy na mieszkanie, czy na transport, a na podstawie swoich decyzji osiedlają się bliżej lub dalej centrum. Można się zatem pokusić o stwierdzenie, że model miasta monocentrycznego jest niczym innym jak rozszerzeniem tradycyjnego modelu wyboru konsumenta - znanego z podstaw ekonomii - zastosowanym na potrzeby wyboru lokalizacji w obrębie miasta [McDonald, 2007].

$Z$ biegiem czasu miasta zaczęły się stawać policentryczne, a ponadto pojawiły się dowody na to, że cena mieszkania nie jest zależna wyłącznie od dystansu, jaki dzieli je od centrum miasta. Stąd model miasta monocentrycznego ewoluował: pojawiły się jego modyfikacje odpowiednie dla miast policentrycznych, a w wycenie mieszkań zaczęto uwzględniać także wiele innych zmiennych, dotyczących cech tak mieszkania i budynku, jak i ich otoczenia. Model miasta monocentrycznego do dziś stanowi podstawę analiz prowadzonych w obszarach ekonomii miasta oraz geografii ekonomicznej [Arnott, 2012, s. 65-69; Glaeser, 2008, s. 8-10].

Podsumowując, odkryty przez von Thünena mechanizm działania renty gruntowej sprawdza się nie tylko w odniesieniu do terenów rolnych, lecz również w odniesieniu do terenów miejskich. W tym przypadku różne rodzaje produkcji rolnej (i różne poziomy renty) zastępuje się przez odpowiednie rodzaje działalności poza-

Rysunek 4.3. Renta miejska a alokacja gruntów dla różnych funkcji

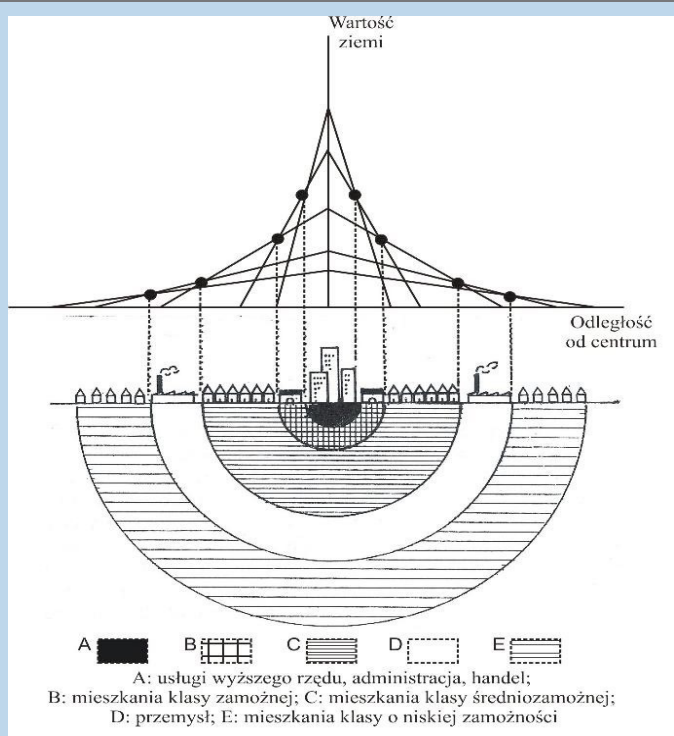

Źródto: Claval, 1976, s. 120 
rolniczej, tj. przez usługi, handel, mieszkalnictwo oraz produkcję przemysłową. Różnicowane wartości ziemi (renty budowlanej) w przestrzeni w warunkach gospodarki rynkowej polega z jednej strony na tym, że najwyższą wartość reprezentują tereny charakteryzujące się najwyższymi korzyściami wynikającymi z przestrzennej koncentracji działalności gospodarczej oraz ludności, natomiast $z$ drugiej strony jest ono konsekwencją realizowanych funkcji. W rezultacie w obszarach centralnych miast obserwuje się najwyższe wartości gruntów, które zajmowane są przez najbardziej dochodowe typy działalności (usługi, handel towarami ekskluzywnymi, mieszka-

Czynniki warunkujące wartość renty w mieście

Wartość dochodu z gruntów jako czynnika produkcji warunkowana jest przede wszystkim przez:

1) Ekonomiczną wydajność gruntów, tj. urodzajność (w przypadku wykorzystania na działalność rolniczą) oraz możliwości intensywnego zagospodarowania gruntu (w przypadku innych rodzajów działalności - handlu, usług, działalności przemysłowej, mieszkań dla gospodarstw domowych).

2) Koszty transportu - wysokość renty jest funkcją odległości od miejsc zapewniających najwyższy poziom korzyści zewnętrznych. Korzyści te w pierwszej kolejności zapewniają centra miast ze względu na najlepszy poziom skomunikowania różnymi środkami transportu, najlepszą dostępność do miejskich usług i infrastruktury czy potencjalnie największą liczbę użytkowników.

Należy przy tym pamiętać, że:

- Wartość terenów w mieście jest przede wszystkim konsekwencją gry popytu i podaży na miejskie nieruchomości.

- Ceny nieruchomości za pośrednictwem mechanizmu renty różnicują sposób wykorzystania terenów na działalność rolniczą (renta rolna) i pozarolniczą (renta budowlana), tj. usługi, handel, przemysł oraz mieszkania dla ludności.

- Wraz z rozwojem miast renta rolna jest wypierana przez rentę budowlaną, a zatem następuje coraz intensywniejsze zagospodarowanie na cele budowlane.

- Użytkownicy miast mają świadomość, że wyższe ceny nieruchomości uwzględniają w znacznym stopniu dostępność do korzyści zewnętrznych generowanych przez otoczenie gruntów najlepiej zlokalizowanych w mieście (dostępność do udogodnień miejskich). Z tego powodu użytkownicy miast nie analizują w swoich decyzjach absolutnych cen nieruchomości, ale relacje cen, np. odnosząc koszt wynajmu mieszkania do poziomu wynagrodzenia oferowanego na miejskim rynku pracy czy też kosztów dojazdu do pracy, lub poziom czynszu płaconego za lokal handlowy do spodziewanego poziomu dochodów ze sprzedaży uzyskiwanych z tytułu dostępności do klientów itp.

Źródto: opracowanie wlasne.

nia dla najbardziej zamożnych grup ludności), natomiast wraz z oddalaniem się od nich grunty miejskie zajmowane są przez tereny przemysłowe, mniej dochodową działalność handlowo-usługową i mniej zamożne gospodarstwa domowe (rys . 4.2). Podejście to podkreśla powszechność działania mechanizmu renty i pozwala domniemywać, że „gra o przestrzeń” miejską w znacznym stopniu zawsze będzie stanowić przede wszystkim wypadkową gry popytu i podaży na grunty i inne rodzaje nieruchomości. 
Ważnym dorobkiem ekonomii miasta jest koncepcja bazy ekonomicznej, która pozwala identyfikować sektory gospodarki, które w największym stopniu decydują o sile gospodarki poszczególnych miast i pozwalają określić ich specjalizację gospodarczą. Podejście to nakazuje wyróżnić w strukturze gospodarczej miast dwa zasadnicze sektory: bazowy (zwany bazą ekonomiczną regionu) oraz niebazowy [McCann, 2001, s. 139]. Sektor bazowy realizuje tzw. funkcje egzogeniczne, czyli wszystkie rodzaje działalności wykonywanych w mieście, które służą zaspokajaniu potrzeb nie tylko miasta, ale również obszarów zewnętrznych. Sektor niebazowy realizuje natomiast funkcje endogeniczne (zwane także funkcjami obsługi), czyli działy gospodarki służące zaspokojeniu potrzeb wyłącznie miejscowej ludności, które rozwijają się, aby obsługiwać sektory bazowe. Motorem wzrostu gospodarczego pozostaje jego baza ekonomiczna, czyli te obszary gospodarki, które wytwarzają dobra i usługi na rynki ponadregionalne i ponadkrajowe. Wzrost produkcji i sprzedaży realizowanych przez bazę ekonomiczną miasta prowadzi przy tym do wzrostu zatrudnienia i ogólnego dochodu zarówno w sektorach bazowych, jak i niebazowych [Edwards, 2007, s. 170].

Kolejna grupa koncepcji w ramach ekonomii miejskiej to modele kształtowania się hierarchii przestrzennej i układów osadniczych. Pozwalają one analizować potencjał gospodarczy miast w odniesieniu do kształtowania się całego układu osadniczego i zostały zapoczątkowane pracami W. Christallera, spośród których najbardziej znana jest teoria ośrodków centralnych [Christaller, 1933]. Autor ten udowodnił, że o randze każdego miasta w strukturze osadniczej regionów i krajów decyduje przestrzenny zasięg sprzedaży oferowanych w nim towarów i usług, wyznaczony przez maksymalną odległość, jaką rozproszona ludność gotowa jest pokonać, aby nabyć oferowane w nim dobra i usługi [Domański, 2006, s. 46]. Odległość ta rośnie wraz z zakresem funkcji pełnionych przez dany ośrodek w przestrzeni. Odległość ta postrzegana jest przy tym w sensie ekonomicznym jako pochodna czasu i kosztów transportu, natomiast ranga ośrodka centralnego stanowi wypadkową liczby jego ludności, rozległości obsługiwanego obszaru oraz zamożności jego mieszkańców. Innymi słowy, o oferowanym „asortymencie” różnorodnych korzyści w poszczególnych ośrodkach systemu osadniczego decydują takie czynniki, jak liczba przedsiębiorstw i gospodarstw domowych oraz wydajność pracy i kapitału, będące w znacznej mierze wypadkową ich koncentracji przestrzennej. Układ ten pozwala domniemywać, że w warunkach zbliżonych do konkurencji doskonałej i relatywnie równomiernie rozwiniętej infrastruktury komunikacyjnej (wpływającej na koszty transportu) układy osadnicze wykazują „naturalną” tendencję do osiągania równowagi poprzez kształtowanie się w nich stosunkowo niewielkiej liczby położonych w jednakowej od siebie odległości ośrodków centralnych oraz znacznie większej liczby ośrodków niższego rzędu.

Rozwinięciem proponowanej przez Christallera teorii ośrodków centralnych jest tzw. ogólna teoria gospodarki przestrzennej, opracowana przez A. Löscha [Lösch, 1940].W jego modelu przyjmuje się, że w procesie produkcji pojawiają się korzyści skali umożliwiające zwiększanie zysku z jednostki produkcji. Jednakże sprzedaż powiększonej produkcji pociąga za sobą rosnące koszty transportu. W konsekwencji przestrzenny układ produkcji jest rezultatem wzajemnego i jednoczesnego oddziaływania korzyści skali i aglomeracji oraz kosztów transportu. Innymi słowy, model Löscha pozwolił na sformalizowaną integrację poprzednich podejść i zwrócił uwagę na to, że w warunkach gospodarki rynkowej system osadniczy miast wykazuje silną tendencję do jednoczesnego rozwoju małej liczby regularnie rozmieszczonych miast dużych (będących ośrodkami centralnymi wyższego rzędu) oraz dużej liczby małych miejscowości, których rynki mają zasięg lokalny. Choć wiele współczesnych 


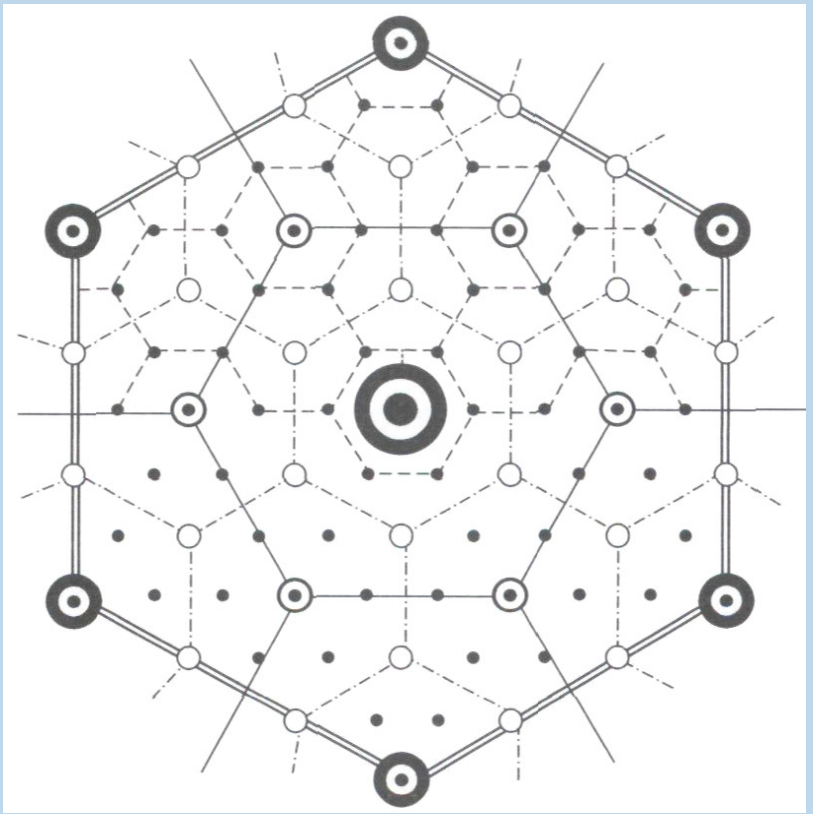

Źródto: Christaller, 1933.

uwarunkowań powoduje, że model ten nie sprawdza się doskonale w rzeczywistości, to jednak pozostaje on wartościowy poznawczo w tym sensie, że wyjaśnia naturalną tendencję do tworzenia się hierarchii osadniczych, w których jednocześnie muszą występować zarówno miasta małe, jak i wielkie.

Modele opisujące regularności w kształtowaniu się hierarchii osadniczej miast sprawdzały się najsilniej w większości państw niemal do połowy XX wieku. Jednakże w latach 60. XX wieku zaczęto dostrzegać, że na skutek coraz silniejszego oddziaływania korzyści skali i aglomeracji w niektórych tylko ośrodkach miejskich tempo ich rozwoju jest tak silne, że rozwijają się one znacznie szybciej od pozostałych. Współczesnym tego wymiarem jest proces metropolizacji gospodarki, gdzie bardzo niewielka liczba ośrodków miejskich zaczyna dominować nie tylko pod względem ludnościowym, ale przede wszystkim z punktu widzenia przejmowania kontroli nad globalnymi procesami gospodarczymi. Proces ten stał się podstawą rozwoju modeli polaryzacyjnych. Odwołują się one do pojęcia bieguna wzrostu, zaproponowanego przez francuskiego ekonomistę F. Perroux, wskazującego, że siły rynkowe nie gwarantują równomiernego wzrostu, gdyż gospodarka wykazuje tendencję do koncentracji [Perroux, 1955]. W abstrakcyjnym definiowaniu przestrzeni ekonomicznej Perroux za biegun wzrostu uznawał nie tyle miasta, ile np. duże przedsiębiorstwo, kompleks przemysłowy, grupę przedsiębiorstw lub gałąź przemysłu określaną jako „przemysł wiodący”, tj. taki, który w określonym momencie cechuje wyższa od przeciętnej w całej gospodarce stopa wzrostu, pozwalająca podejmować w nim szybciej produkcję na wielką skalę oraz koncentrować w nim kapitał. Poprzez powiązania z innymi gałęziami gospodarki bieguny wzrostu stają się siłą napędową jej rozwoju. Wymiar przestrzenny koncepcji biegunów wzrostu nadał J.R. Boudeville, który 
wskazał, że pomimo tego, na co wskazuje Perroux (prezentujący podejście sektorowe), istnieją bieguny wzrostu posiadające wymiar ściśle przestrzenny i są regiony i miasta, które w danym momencie cechuje szybsze niż przeciętne tempo wzrostu liczby ludności i tempo wzrostu gospodarczego [Boudeville, 1972].

Teoria polaryzacji akcentuje zatem endemiczność zjawiska polegającego na niezrównoważonym przestrzennie charakterze wzrostu i rozwoju gospodarczego. Ważny wkład w jej rozwinięcie mieli także ekonomiści G. Myrdal i A.O. Hirschman. Pierwszy z nich akcentował, że o formowaniu się układów osadniczych decydują dwa przeciwstawne efekty: 1) wymywania kapitału, ludności i innych zasobów do najbardziej dynamicznie rozwijających się obszarów (przede wszystkim wielkich aglomeracji miejskich) (backwash effects) oraz 2) rozprzestrzeniania (spread effects) procesów rozwojowych tychże obszarów w kierunku peryferyjnym. Według prognoz Myrdala siła efektów rozprzestrzeniania jest w praktyce gospodarczej zbyt słaba w stosunku do efektów wymywania i przy braku interwencji sektora publicznego w procesy rozwoju przestrzennego najsilniej rozwijające się miasta coraz bardziej dominują nad pozostałymi obszarami. Innymi słowy, proces polaryzacji staje się wraz ze wzrostem gospodarczym zjawiskiem nieuniknionym [Myrdal, 1957]. Z kolei Hirschman, w przeciwieństwie do Myrdala, prezentuje pozytywne podejście do koncepcji polaryzacji, zakładając, że z czasem efekty rozprzestrzeniania zaczną dominować na efektami wymywania jako efekt pojawienie się dominacji niekorzyści aglomeracji w biegunach wzrostu oraz dyfuzji kapitału i technologii do miast i regionów słabiej rozwiniętych [Hirschman, 1957].

Powyższe rozważania pozostają do dziś silnie obecne w dyskusji nad przyczynami i konsekwencjami zróżnicowań przestrzennych rozwoju gospodarczego, nie dając jednak jednoznacznej odpowiedzi na pytanie, czy procesy polaryzacji przestrzennej da się skutecznie zahamować. Za najbardziej wpływowe w ostatnich latach uznaje się prace P. Krugmana - laureata Nagrody Banku Szwecji im. Alfreda Nobla w dziedzinie ekonomii z 2008 roku. Jego publikacje z początku lat 90 . XX wieku [m.in. 1991a, 1991b] są uznawane za umowny początek nurtu badawczego zwanego Nową Geografią Ekonomiczną (NGE). Podstawowym celem tej gałęzi ekonomii pozostaje poszukiwanie równowagi ogólnej w decyzjach lokalizacyjnych przedsiębiorstw i gospodarstw domowych poprzez jednoczesną analizę sił dośrodkowych i odśrodkowych kierujących tymi decyzjami. W ogólnym zarysie model Krugmana zakłada, że na skutek działania wzrastających przychodów oraz w warunkach wystę-

Nieuchronność procesów polaryzacji? Przykład współczesnego przemysłu muzycznego

Najpopularniejsze gwiazdy muzyki pop odnosiły swe sukcesy przede wszystkim za sprawą trzech miast: Londynu, Nowego Jorku oraz Los Angeles. W swej analizie P. Adler posłużył się danymi na temat wykonawców muzycznych, których twórczość sprzedawała się najlepiej pomiędzy rokiem 1950 a 2010. Na tej podstawie zidentyfikowano miejsca: 1) w których ci artyści się urodzili; 2) gdzie zamieszkali, kiedy ich utwór stał się przebojem oraz 3) gdzie nagrywano ich albumy. Adler zauważył, że spośród 258 najpopularniejszych artystów muzyki pop w latach 1950-2010 aż 13,7\% urodziło się w Nowym Jorku, 6,6\% w Londynie, a 2,2\% w Los Angeles. Ciekawsze jest jednak to, że więcej artystów zamieszkiwało te miasta, kiedy ich utwory stawały się przebojami: odpowiednio 21,0\% w Nowym Jorku, 22,3\% w Londynie oraz 19,8\% w Los Angeles [Florida, 2015]. Zatem miasta te przyciągały do siebie muzyków, którzy właśnie w nich rozwijali swoje kariery i stawali się gwiazdami na skalę światową. Można zatem pokusić się o stwierdzenie, że przemysł muzyczny koncentrujący się we wskazanych trzech miastach i stwarzający 
w nich warunki do rozwoju artystom najprawdopodobniej przyczyniał się do zaistnienia efektów wymywania, ponieważ muzycy decydowali się na przenosiny do tych miast, porzucając swoje rodzinne strony.

Rysunek 4.5. Ścieżki karier 258 największych gwiazd muzyki pop w latach 1950-2010

Źródto: Opracowanie własne na podstawie Florida, 2015.

powania dodatnich $\mathrm{i}$ istotnych kosztów transportu producenci lokalizują się blisko siebie (dochodzi do aglomeracji). Z drugiej strony przy jednoczesnej niemobilności niektórych zasobów (gruntów oraz częściowo także pracy) koszty transportu działają jako siła odśrodkowa - przeciwdziałająca procesom aglomeracji [Domański, 2010, s. 43]. Napięcie między tymi dwiema siłami (gdzie nawet drobna zmiana parametrów analizowanego przez Krugmana modelu może decydować w różnym czasie zamiennie o przewadze sił aglomeracyjnych bądź równie dobrze o przewadze sił dośrodkowych) kształtuje ewolucję przestrzennej struktury gospodarki. Co istotne, model NGE wskazuje, że systemy osadnicze w rzeczywistości nie dążą do równowagi, ale ulegają ciągłym zmianom na skutek dynamicznie zmieniających się sił sprzyjających zarówno koncentracji, jak i dekoncentracji gospodarki [Sokołowicz, 2015].

Ostatnia ważna grupa koncepcji przydatnych na gruncie ekonomii miasta odwołuje się do pojęcia rozwoju endogenicznego. Rozwinęła się ona na gruncie zasadniczej zmiany sposobu myślenia o procesach rozwoju lokalnego i regionalnego, która została zapoczątkowana w latach 70. XX wieku. Okazało się, że dotychczasowe teorie w sposób niewystarczający wyjaśniały zjawiska zachodzące w przestrzeni przede wszystkim dlatego, że miały charakter uniwersalny, podczas gdy zaczęto dostrzegać, że o sukcesie gospodarczym wielu miast i regionów decyduje również ich wewnętrzny, specyficzny potencjał. Odnotowano tym samym lukę w badaniach nad procesami rozwoju lokalnego i regionalnego, która poza prawami uniwersalnymi identyfikować powinna także czynniki różnicujące jednostki osadnicze. W tym kontekście ekonomiści zaczęli poszukiwać przyczyn nowych czynników rozwoju miast i regionów o charakterze oddolnym (endogenicznym), czyli zależnym od wewnętrznych uwarunkowań społecz- 
no-gospodarczych. W ramach koncepcji rozwoju endogenicznego, w odróżnieniu od wcześniej omawianych modeli, nie wypracowano jednolitego aparatu pojęciowego i badawczego. W konsekwencji podejście to pozostaje konglomeratem różnych podejść, wśród których da się jednak wyróżnić następujące wspólne założenia:

- Każde miasto i region stanowią specyficzne układy przestrzenne, z własną historią, mieszkańcami, ich kompetencjami i relacjami społecznymi - tym samym rozwój tych obszarów wynika nie tylko z praw uniwersalnych, ale także z ich wewnętrznej dynamiki.

- Powyższe uwarunkowania nakazują poszukiwać wewnętrznych źródeł konkurencyjności, opartych na specyficznych zasobach materialnych i niematerialnych.

- Do najważniejszych czynników rozwojowych miast należy zaliczyć kapitał ludzki i kapitał społeczny oraz jakość funkcjonowania instytucji - dlatego trzeba położyć duży nacisk na edukację mieszkańców i budowanie zaufania społecznego oraz sieci relacji gospodarczych, jak również rozwój partycypacji i dialogu jako metody rządzenia oraz silnego zaangażowania partnerów z sektora przedsiębiorstw oraz sektora obywatelskiego w planowanie rozwoju miast.

- O zdolności miast do konkurowania decyduje nie tylko ich wewnętrzny potencjał (specjalizacja w nowoczesnych sektorach gospodarki, kreatywność mieszkańców), lecz także otwartość na otoczenie krajowe i międzynarodowe (jako źródło nowych pomysłów oraz rynek zbytu) i zdolność dostosowania się do zmieniających się uwarunkowań zewnętrznych (miasta kreatywne powinny być jednocześnie miastami inteligentnymi i uczącymi się).

Ważne jest przy tym, aby rozwój gospodarczy kraju stanowił wypadkową rozwoju miast i regionów, w odróżnieniu od okresu minionego, w którym postrzegany był on jako pochodna wysokiej dynamiki wzrostu gospodarczego państwa [Pietrzyk, 2001, s. 18]. Rozwój koncepcji rozwoju endogenicznego wśród naukowców skutkuje też przeobrażeniami w domenie polityki rozwoju miast i regionów. We wcześniejszych okresach programowania stosowano ten sam model polityki regionalnej dla wszystkich, nieuwzględniający specyficznych uwarunkowań terytorialnych [Rodriguez-Pose, 2010]. Wynikało to z przekonania, że dające się replikować w różnych lokalizacjach odgórne narzędzia w zakresie rozwoju infrastruktury, edukacji czy polityki przemysłowej wystarczą do wspierania wzrostu gospodarczego i eliminowania dysproporcji rozwojowych, i nie muszą uwzględniać lokalnego kontekstu instytucjonalnego [Pike, Rodriguez-Pose, 2006]. Od trzydziestu lat natomiast postuluje się nacisk na decentralizację władzy i przekazanie istotnej autonomii decyzyjnej władzom samorządowym i obywatelom w systemie rządzenia w celu eksponowania indywidualnych dla poszczególnych jednostek terytorialnych czynników sukcesu w rozwoju społecznym i gospodarczym.

\subsection{Sektor publiczny w ekonomii miasta}

W gospodarce rynkowej miasta stanowią z jednej strony efekt procesów gospodarczych opartych na wyborach lokalizacyjnych przedsiębiorstw i gospodarstw domowych, jednak z drugiej strony są one przestrzeniami, w których najostrzej uwidaczniają się niedoskonałości rynku. Ze względu na istotną koncentrację w przestrzeni wielu użytkowników miast pojawia się m.in. ryzyko tzw. pokusy nadużycia (moral hazard), czyli zachowań oportunistycznych, które wpływają negatywnie na poziom użyteczności innych aktorów ekonomicznych. Stanowi to przesłankę dla tworzenia systemu instytucjonalno-prawnego (ograniczającego nadużycia na miejskich rynkach pracy, nieruchomości czy też w transporcie zbiorowym), który 
Tabela 4.2. Podstawowe modele ekonomiczne wykorzystywane w ekonomii miasta

\begin{tabular}{|c|c|c|c|c|}
\hline Koncepcja & $\begin{array}{c}\text { Okres } \\
\text { powstania }\end{array}$ & $\begin{array}{c}\text { Kluczowi } \\
\text { przedstawiciele }\end{array}$ & Czynniki wyjaśniane & Czynniki wyjaśniające \\
\hline $\begin{array}{l}\text { Modele } \\
\text { renty } \\
\text { gruntowej } \\
\text { i budow- } \\
\text { lanej }\end{array}$ & $\begin{array}{l}\text { Lata } 20 . \\
\text { XIX wieku } \\
\text { (renesans } \\
\text { myśli } \\
\text { w latach 60. } \\
\text { XX wieku) }\end{array}$ & $\begin{array}{l}\text { Johann H. } \\
\text { von Thünen } \\
\text { William Alonso }\end{array}$ & $\begin{array}{l}\text { wartość renty grun- } \\
\text { towej (dochodów } \\
\text { z gruntu) } \\
\text { wartość terenów } \\
\text { w mieście } \\
\text { rodzaje działalności } \\
\text { gospodarczej } \\
\text { w przestrzeni } \\
\text { i sposób ich roz- } \\
\text { mieszczenia }\end{array}$ & $\begin{array}{l}\text { odległość od miejsc } \\
\text { o najwyższej użytecz- } \\
\text { ności (np. od centrum } \\
\text { miasta) } \\
\text { koszty transportu } \\
\text { urodzajność gruntów } \\
\text { oraz możliwości ich } \\
\text { intensywnego zabudo- } \\
\text { wania } \\
\text { dochodowość poszcze- } \\
\text { gólnych rozdziałów dzia- } \\
\text { talności gospodarczej }\end{array}$ \\
\hline $\begin{array}{l}\text { Koncepcja } \\
\text { bazy ekono- } \\
\text { micznej }\end{array}$ & $\begin{array}{l}\text { Lata } 40 . \text { i } 50 . \\
\text { XX wieku }\end{array}$ & $\begin{array}{l}\text { Werner Sombart } \\
\text { Richard B. Andrews } \\
\text { John M. Keynes }\end{array}$ & $\begin{array}{l}\text { sektory gospodarki } \\
\text { będące siłą napę- } \\
\text { dową rozwoju miast }\end{array}$ & $\begin{array}{l}\text { podział na podstawowe } \\
\text { sektory gospodarki } \\
\text { (bazę ekonomiczną) oraz } \\
\text { na sektory wspoma- } \\
\text { gające }\end{array}$ \\
\hline $\begin{array}{l}\text { Modele } \\
\text { kształto- } \\
\text { wania się } \\
\text { hierarchii } \\
\text { przestrzen- } \\
\text { nej } \\
\text { i układów } \\
\text { osadniczych }\end{array}$ & $\begin{array}{l}\text { Lata } 30 . \\
\text { XX wieku }\end{array}$ & $\begin{array}{l}\text { Walter Christaller } \\
\text { August Lösch }\end{array}$ & $\begin{array}{l}\text { struktura hierarchii } \\
\text { osadniczej miast } \\
\text { ranga poszczegól- } \\
\text { nych miast w struk- } \\
\text { turze osadniczej }\end{array}$ & $\begin{array}{l}\text { zasięg rynków zbytu na } \\
\text { dobra i usługi oferowa- } \\
\text { ne w miastach } \\
\text { wielkość miast mierzona } \\
\text { liczbą mieszkańców } \\
\text { odległość między mia- } \\
\text { stami }\end{array}$ \\
\hline $\begin{array}{l}\text { Modele } \\
\text { polaryza- } \\
\text { cyjne }\end{array}$ & $\begin{array}{l}\text { Lata 60. i } 70 . \\
\text { XX wieku } \\
\text { (renesans } \\
\text { myśli } \\
\text { w latach } \\
\text { 90. XX wieku) }\end{array}$ & $\begin{array}{l}\text { François Perroux } \\
\text { Jacques R. Boudeville } \\
\text { Gunnar Myrdal } \\
\text { - Albert O. Hirschman } \\
\text { Paul Krugman }\end{array}$ & $\begin{array}{l}\text { struktura hierarchii } \\
\text { osadniczej miast } \\
\text { napięcie między } \\
\text { siłami sprzyjającymi } \\
\text { polaryzacji (rozwój } \\
\text { największych miast } \\
\text { jako biegunów } \\
\text { wzrostu) a siłami } \\
\text { prowadzącymi do } \\
\text { rozprzestrzeniania } \\
\text { rozwoju z wielkich } \\
\text { miast do peryferii }\end{array}$ & $\begin{array}{l}\text { wielkość miasta mierzo- } \\
\text { na liczbą mieszkańców } \\
\text { siła korzyści skali } \\
\text { i korzyści aglomeracji } \\
\text { koszty transportu } \\
\text { polityka rozwoju miast }\end{array}$ \\
\hline $\begin{array}{l}\text { Koncepcje } \\
\text { rozwoju } \\
\text { endogenicz- } \\
\text { nego }\end{array}$ & $\begin{array}{l}\text { Lata } 80 . \\
\text { i } 90 . X X \\
\text { wieku oraz } \\
\text { początek XXI } \\
\text { wieku }\end{array}$ & $\begin{array}{l}\text { John R. Friedmann } \\
\text { Giacomo Becattini } \\
\text { Philippe Aydalot } \\
\text { Allen J. Scott } \\
\text { - Michael Storper } \\
\text { Ann Saxenian } \\
\text { Denis Maillat } \\
\text { - Philip McCann } \\
\text { - Richard Florida } \\
\text { Charles Landry }\end{array}$ & $\begin{array}{l}\text { czynniki konkuren- } \\
\text { cyjności miast } \\
\text { przyczyny różnic } \\
\text { w specyficznych } \\
\text { uwarunkowaniach } \\
\text { rozwojowych jedno- } \\
\text { stek osadniczych }\end{array}$ & $\begin{array}{l}\text { specyficzne zasoby ma- } \\
\text { terialne i niematerialne } \\
\text { jakość kapitału ludz- } \\
\text { kiego } \\
\text { poziom zaufania i kapi- } \\
\text { tału społecznego } \\
\text { jakość lokalnych insty- } \\
\text { tucji formalnych i niefor- } \\
\text { malnych }\end{array}$ \\
\hline
\end{tabular}

Źródto: opracowanie własne. 
ma na celu zapewnienie racjonalnej gospodarki i efektywnej alokacji praw własności w przestrzeni. Ponadto w społecznościach miejskich siłą rzeczy pojawiać się będą rozbieżności między interesami pojedynczych przedsiębiorstw i osób a szeroko rozumianym dobrem społecznym. Często krótkookresowe cele mieszkańców i przedsiębiorców oraz małych grup interesów nie będą spójne z celami długookresowymi rozwoju miasta. Stąd zapewnienie strategicznych celów rozwoju (poprzez planowanie strategiczne) także przypisuje się domenie publicznej w mieście, reprezentowanej przede wszystkim przez władze samorządowe. Te ostatnie pozostają ponadto odpowiedzialne za koordynację działań różnorodnych użytkowników miast oraz mediacje w przypadku nieuniknionych w miastach konfliktów przestrzennych. W ekonomii miasta funkcjonowanie sektora publicznego w mieście uzasadnia się faktem występowania dóbr publicznych, efektów zewnętrznych oraz monopolu naturalnego [Glaeser, 2008, s. 28].

\subsubsection{Dobra publiczne}

W modelu konkurencji doskonałej zakłada się, że wszystkie dobra na rynku są wyłącznie dobrami prywatnymi. Innymi słowy, z dóbr korzystają wyłącznie ich właściciele. Dobrami prywatnymi są zatem domy i mieszkania, ubrania lub urządzenia elektroniczne. W rzeczywistości poza dobrami prywatnymi istnieje szereg dóbr publicznych, które można opisać dwoma podstawowymi cechami: 1) nie istnieje możliwość wyłączenia kogokolwiek z ich konsumpcji; 2) nie zachodzi konkurencja w konsumpcji tego dobra.

Zakładając, że nikogo nie można wyłączyć z konsumpcji dobra publicznego, pojawia się sytuacja, kiedy każdy - nie tylko właściciele - jest dopuszczony do korzystania z tego dobra (np. każdemu obywatelowi przysługuje prawo do skorzystania z pomocy policji lub straży miejskiej). Z kolei brak konkurencji w konsumpcji dobra publicznego oznacza, że każda kolejna osoba korzystająca z tego dobra nie umniejsza jego ilości, którą konsumować może następna osoba (przykładem może być tutaj piękny widok - gdy jedna osoba się nim zachwyca, nie przeszkadza to kolejnej osobie w jego podziwianiu).

Okazuje się jednak, że istnieje ograniczona ilość czystych dóbr publicznych, ponieważ pomiędzy dobrami publicznymi i prywatnymi istnieją jeszcze tzw. dobra mieszane, za które uważa się dobra klubowe i wspólne zasoby [Zaucha, 2010b, s. 40-43]. Dobrami klubowymi są te dobra, które mogą być jednocześnie konsumowane przez wiele osób bez uszczerbku dla ilości tego dobra dostępnej dla pozostałych, a jednocześnie konsumpcja tego dobra jest ograniczona dla pewnej części społeczeństwa (np. szkoła, z której mogą korzystać bez wyjątku wszystkie kolejne pokolenia dzieci, choć szkoła nie jest dobrem konsumowanym bezpośrednio przez liczną społeczność dorosłych). Z kolei wspólne zasoby są takimi dobrami, o które ludzie ze sobą konkurują, a jednocześnie nikogo z ich konsumpcji wykluczyć nie można. Oznacza to, że zbyt duża liczba osób, które chciałyby skorzystać ze wspólnych zasobów, może być zgubna dla możliwości odtworzenia takiego dobra. Zjawisko to często obserwujemy w przypadku wykorzystywania zasobów naturalnych, np. nadmierne wykorzystywanie łowisk może skutkować ich szybkim wyczerpaniem [Ostrom, 1990].

Warto zauważyć, że zasób dóbr publicznych i dóbr mieszanych jest różny w zależności od lokalizacji w przestrzeni, ponieważ znaczna część dóbr publicznych jest trwale związana z określonym miejscem w przestrzeni. Dobra publiczne i dobra mieszane stanowią zatem część oferty udogodnień miejskich. Przykładowo nie każdy rejon miasta jest wyposażony w publiczny park. A zatem jeżeli gospodarstwo 
domowe, które zamieszkuje taki rejon, chciałoby spędzić czas wolny właśnie w parku, byłoby zmuszone pokonać odpowiednią odległość, aby się do niego dostać. Konieczność pokonania odległości wiąże się m.in. z ponoszeniem kosztów (np. zakupu biletu tramwajowego). Ponieważ nie wszystkie gospodarstwa domowe mogą sobie pozwolić na ponoszenie takich kosztów, immobilność dóbr w przestrzeni może stanowić dla nich istotną barierę na drodze do zaspokajania ich potrzeb i uzyskiwania satysfakcji. Jest to jeden z powodów, dla których istnieje planowanie przestrzenne jako aktywność władz lokalnych: jego zadaniem jest m.in. swoiste „przybliżanie” immobilnych dóbr do tych, którzy ich potrzebują, poprzez minimalizację kosztów docierania do tychże dóbr [Klaassen, 1988, s. 187-189].

Tabela 4.3. Podział dóbr ze względu na konkurencyjność w konsumpcji oraz wyłączność z konsumpcji

\begin{tabular}{|c|c|c|c|}
\hline & & \multicolumn{2}{|c|}{ MOŻLIWOŚĆ WYKLUCZENIA Z KONSUMPCJ } \\
\hline & & TAK & NIE \\
\hline \multirow{2}{*}{$\begin{array}{l}\text { KONKURENCYJNOŚĆ } \\
\text { W KONSUMPCJI }\end{array}$} & TAK & $\begin{array}{l}\text { DOBRA PRYWATNE } \\
\text { Przykłady: dobra nabywane } \\
\text { w sklepach osiedlowych } \\
\text { i centrach handlowych, kawa } \\
\text { wypita w kawiarni, samochody } \\
\text { osobowe. }\end{array}$ & $\begin{array}{l}\text { DOBRA MIESZANE: } \\
\text { WSPÓLNE ZASOBY } \\
\text { Przykłady: park miejski, } \\
\text { usługi transportu zbiorowego. }\end{array}$ \\
\hline & NIE & $\begin{array}{l}\text { DOBRA MIESZANE: } \\
\text { DOBRA KLUBOWE } \\
\text { Przykłady: kina, szkoły, baseny. }\end{array}$ & $\begin{array}{l}\text { DOBRA PUBLICZNE } \\
\text { Przykłady: oświetlenie ulic, } \\
\text { bezpieczeństwo w mieście. }\end{array}$ \\
\hline
\end{tabular}

Źródto: opracowanie wlasne na podstawie Brown, Jackson, 1990.

\subsubsection{Efekty zewnętrzne}

Choć w modelu konkurencji doskonałej twierdzono, że otoczenie nie oddziałuje na jednostkę, zaczęto podważać to założenie. W rezultacie do teorii ekonomii wprowadzono pojęcie efektów zewnętrznych, będących skutkami działań pojedynczych podmiotów, wpływającymi na poziom użyteczności pozostałych jednostek, które to jednostki nie mają jednak bezpośredniego wpływu ani na siłę, ani na kierunek tych oddziaływań. Zainteresowanie efektami zewnętrznymi znalazło podatny grunt w obszarze ekonomii miasta za sprawą tego, że miasta stanowią silną koncentrację ludności, zabudowy i działalności gospodarczej. Z tego powodu miasta w ujęciu ekonomicznym analizowane są jako źródła korzyści wynikających z ich rozwoju (m.in. łatwość dostępu do dóbr i usług, do pracowników, do usług publicznych świadczonych w mieście, do dobrodziejstw rozwiniętych i szerokich rynków pracy) oraz jako źródła zjawisk niekorzystnych (m.in. zatłoczenia komunikacyjnego, zanieczyszczenia środowiska, zagrożenia przestępczością).

Dziś wiadomo już, że otoczenie może oddziaływać pozytywnie na jednostkę, co skutkuje tzw. pozytywnymi efektami zewnętrznymi (korzyściami zewnętrznymi, których odmianą są opisywane wcześniej korzyści aglomeracji). Przykładowo skupienie na jednej ulicy dużej liczby sklepów z tym samym asortymentem powoduje, 
że ulica ta staje się rozpoznawalna dla klientów poszukujących konkretnych towarów. W tej sytuacji kolejnym sklepikarzom może się opłacać lokalizowanie swojego biznesu na tej samej ulicy - nawet pomimo wyższych czynszów i konkurencji ze strony innych sklepów oferujących podobne towary - ponieważ w ten sposób sklepikarze ci zapewniają sobie dostęp do potencjalnie większej liczby klientów, którzy kojarzą tę ulicę z określonym rodzajem asortymentu. Przykładem korzyści zewnętrznych w mieszkalnictwie może być z kolei gotowość do płacenia wyższych czynszów w rejonach miasta o lepszej ofercie udogodnień, gdzie dzięki podejmowanym wcześniej przez inne podmioty inwestycjom są one bardzo dobrze skomunikowane, oferują dostęp do szkół, przedszkoli, sklepów, podstawowych usług lub terenów zielonych.

Oddziaływanie otoczenia na jednostkę może mieć także charakter negatywny, co skutkuje negatywnymi efektami zewnętrznymi (niekorzyściami zewnętrznymi, niekorzyściami aglomeracji). Można tu posłużyć się przykładem ruchu samochodowego. W miarę jak liczba użytkowników samochodów na drogach rośnie, w mieście może pojawić się zjawisko tzw. kongestii (zatłoczenia, zakorkowania), ponieważ każdy kolejny kierowca samochodu, który będzie chciał przejechać określoną drogą, będzie umniejszał jej przejezdność dla pozostałych kierowców. Kierowcy nie mają zatem bezpośredniego wpływu na poziom tego zatłoczenia (nie decydują o tym, ilu innych kierowców wyjedzie danego dnia na drogi), a jednak ponoszą jego konsekwencje, spędzając coraz więcej czasu w korkach ulicznych. Innym przykładem niekorzyści zewnętrznych związanych z ruchem ulicznym jest emisja zanieczyszczeń przez samochody. Wysokie natężenie ruchu samochodów powoduje wyższe zanieczyszczenie powietrza w danym rejonie miasta, co negatywnie oddziałuje na mieszkańców tego rejonu.

Efekty zewnętrze mogą powstawać w dwojaki sposób. Po pierwsze, mogą one stanowić niezamierzony efekt działania poszczególnych podmiotów (np. celem wspomnianych kierowców nie jest zanieczyszczanie powietrza - powstaje ono wskutek ich chęci przemieszczania się samochodem). W drugiej sytuacji efekty zewnętrzne tworzy się celowo (np. władze miasta mogą prowadzić politykę przyciągania sklepów operujących w określonej branży na daną ulicę, aby ją ożywić).

Wskazuje się, że o ile w polityce prowadzonej na szczeblu krajowym negatywne efekty zewnętrzne częściej minimalizuje się poprzez nakładanie opłat (np. handel prawami do emisji dwutlenku węgla), na poziomie lokalnym częściej niekorzyści te poddaje się regulacji niż opodatkowaniu [Arnott, 2012, s. 70]. Przykładem niech będzie wyznaczanie lokalizacji najbardziej uciążliwych zakładów przemysłowych (np. za sprawą zanieczyszczenia hałasem) z dala od zabudowań mieszkalnych. Nie oznacza to, że władze miasta ograniczają się wyłącznie do działań z zakresu regulacji i nie stosują opodatkowania w celu minimalizacji niekorzyści zewnętrznych - np. władze wielu miast nakładają na użytkowników samochodów dodatkowe opłaty za wjazd do centrum, co ogranicza w nich kongestię.

Występowanie efektów zewnętrznych uzasadnia prowadzenie polityki władz miejskich. Jak wskazano wcześniej, ekonomiczny punkt widzenia zakłada, że każdy powinien mieć możliwość swobodnego wyboru miejsca zamieszkania. Należy jednak zwrócić uwagę na sytuację, w której indywidualne dążenia ludzi do osiągania własnej satysfakcji w zakresie miejsca zamieszkania mogą skutkować niekorzyściami zewnętrznymi dla pozostałej części lokalnej społeczności. Przykładowo gospodarstwo domowe, które postanowi zamieszkać z dala od uzbrojonych terenów miejskich, w które już zainwestowano, narazi w ten sposób samorząd miejski na relatywnie wysokie wydatki, które musiałyby zostać poniesione, aby zapewnić temu gospodarstwu dostęp do podstawowej infrastruktury, takiej jak wodociąg, kanalizacja, gazociąg czy sieć elektroenergetyczna. Stąd miasta w drodze planowania przestrzennego decy- 
dują się regulować rozmiar obszaru, na którym dozwolone jest wznoszenie nowej zabudowy, co chroni je przed nadmiernymi kosztami funkcjonowania, którymi obarczona byłaby cała społeczność miejska.

Efekty zewnętrzne jako jedna z podstawowych kategorii ekonomicznych w mieście

Istotna cecha efektów zewnętrznych - zarówno w produkcji, jak $i$ w konsumpcji-jest fakt, że sa to dobra, które interesuja ludzi (którzy albo chca mieć dostęp do korzyści, albo chca unikać niekorzyści), ale nie sa sprzedawane na rynku. Dlatego alokacja tych dóbr nie może być efektywna z ekonomicznego punktu widzenia [Varian, 2001, s. 574].

Rodzaje korzyści zewnętrznych, które wynikaja bezpośrednio z funkcjonowania $w$ mieście, nazywa się odpowiednio korzyściami i niekorzyściami aglomeracji. W pierwszym ujęciu miasta sprzyjają innowacji, efektywności produkcji, rozwojowi handlu i tym samym pozwalaja podwyższać jakość życia. W ujęciu drugim miasta są hałaśliwe, zanieczyszczone $i$ zattoczone. Jednak mimo wszystko większość przedsiębiorstw i gospodarstw domowych wykazuje się skłonnościa do dziatania i życia w miastach, bowiem koszty (także zewnętrzne) z tym związane sa z nadwyżka rekompensowane przez korzyści [O'Sullivan, 2007, s. 1].

\subsubsection{Monopol naturalny}

Wydawać by się mogło, że w każdym przypadku powinno istnieć wystarczająco wiele przedsiębiorstw konkurujących ze sobą o dostarczanie konsumentom określonego dobra lub usługi, aby w rezultacie żadne z nich nie mogło samodzielnie kształtować sytuacji na rynku. Warto jednak zauważyć, że istnieją także takie uwarunkowania, w których uzasadnione jest istnienie tylko jednego podmiotu dostarczającego dane dobro lub usługę. Zjawisko to określa się mianem monopolu naturalnego, który jest uzasadniony przede wszystkim występowaniem znacznych korzyści skali, co oznacza, że koszt jednostkowy wytworzenia dobra lub usługi spada wraz ze wzrostem produkcji. Innymi słowy, aby taki podmiot mógł funkcjonować, konieczne jest istnienie wystarczająco dużej liczby konsumentów (będących odbiorcami dóbr lub usług tego podmiotu) oraz poniesienie dużych nakładów inwestycyjnych już w momencie rozpoczynania działalności. Przypadek monopolu naturalnego wiąże się również z sytuacją, kiedy proces technologiczny nie może być podzielony między kilka innych podmiotów oraz wtedy, kiedy bieżąca działalność cechuje się wysokimi kosztami stałymi. Przykładowo z sytuacją monopolu naturalnego w mieście można się spotkać w przypadku przedsiębiorstw z obszaru gospodarki wodno-ściekowej. Zazwyczaj na miejskim rynku istnieje tylko jedno przedsiębiorstwo odpowiedzialne za wodociągi i kanalizację - tworzenie drugiego podmiotu o tym samym zakresie zadań byłoby utrudnione ze względu na niepodzielność wymaganej infrastruktury, a jej dublowanie nie znajdowałoby uzasadnienia ekonomicznego. Podsumowując, monopol naturalny występuje w sytuacji, kiedy względy techniczne, ekonomiczne lub organizacyjne nie uzasadniają prowadzenia danej działalności przez więcej niż jeden podmiot gospodarczy. 


\section{Bibliografia}

Arnott R. (2012), What Planners Need To Know About The "New Urban Economics", [w:] N. Brooks, K. Donaghy, G.J. Knaap (red.), The Oxford Handbook of Urban Economics and Planning, Oxford University Press, Oxford.

Benko G. (1993), Geografia technopolii, Państwowe Wydawnictwo Naukowe PWN, Warszawa.

van den Berg L. et al. (1982), Urban Europe. A Study of Growth and Decline, Pergamon Press, Kronberg im Taunus.

Boudeville J.R. (1972), Aménagement du territoire et polarisation, Editions M.-Th. Genin Librairies Techniques, Paris.

Brown C.V., Jackson P.M. (1990), Public Sector Economics, Basic Blackwell, Oxford.

Bury P., Markowski T., Regulski J. (1993), Podstawy ekonomiki miasta, Fundacja Rozwoju Przedsiębiorczości, Łódź.

Christaller W. (1933), Die Zentralen Orte in Süddeutschland. Eine ökonomisch-geographische Untersuchung über die Gesetzmässigkeit der Vorbereitung und Entwicklung der Siedlungen mit städtischen Funktionen, Verlag von Gustav Fischer, Jena.

Claval P. (1976), Éléments de géographie économique, Editions M.-Th. Genin Librairies Techniques, Paris.

Diamond D.B., Tolley G.S. (1982), The Economic Roles of Urban Amenities, [w:] D.B. Diamond, G.S. Tolley (red.), The Economics of Urban Amenities, Academic Press, New York.

Domański R. (2006), Gospodarka przestrzenna. Podstawy teoretyczne, PWN, Warszawa.

Domański R. (2010), Nowa geografia ekonomiczna według Paula Krugmana, [w:] W.M. Gaczek (red.), Prace z gospodarki przestrzennej, Zeszyty Naukowe Uniwersytetu Ekonomicznego w Poznaniu Nr 161, Wydawnictwo Uniwersytetu Ekonomicznego w Poznaniu, Poznań.

Dziemianowicz W. (1997), Kapitał zagraniczny a rozwój regionalny i lokalny w Polsce, Euroreg, Warszawa.

Edwards M.E. (2007), Regional and Urban Economics and Economic Development. Theory and Methods, Auerbach Publications, Taylor and Francis Group, New York.

Florida R. (2015), The Geography of Pop Music Superstars, CityLab, http://www.citylab.com/tech/2015/08/the-geography-of-pop-music-superstars/402445/. Data dostępu: 28.08.2015 r.

Glaeser E.L. (2008), The Economic Approach to Cities, Harvard Institute of Economic Research Discussion Paper No. 2149, Cambridge.

Glaeser E.L., Kolko J., Saiz A. (2001), Consumer city, „Journal of Economic Geography”, $\mathrm{nr}$ 1(1).

Godlewska H. (2001), Lokalizacja działalności gospodarczej, Wyższa Szkoła Handlu i Finansów Międzynarodowych, Warszawa.

Goodall B. (1972), The Economics of Urban Areas, Pergamon Press, Oxford.

Gorzelak G. (2008), Miasto jako przedmiot badań ekonomii, [w:] B. Jałowiecki (red.), Miasto jako przedmiot badań naukowych w początkach XXI wieku, Wydawnictwo Naukowe „Scholar”, Warszawa.

Grosse T.G. (2002), Przeglą koncepcji teoretycznych rozwoju regionalnego, „Studia Regionalne i Lokalne", nr 1(8), Warszawa. 
Hirschman A.O. (1957), Investment Policies and Dualism in Underdeveloped Countries, „American Economic Review”, nr 47(5).

Ikeda S. (2007), Urbanizing economics, „The Review of Austrian Economics”, nr 20(4). Klaassen L.H. (1988), Myśl i praktyka ekonomiczna a przestrzeń, Wydawnictwo Uniwersytetu Łódzkiego, Łódź.

Krugman P. (1991a), Geography and trade, MIT Press, Cambridge.

Krugman P. (1991b), Increasing Returns and Economic geography, „Journal of Political Economy", nr 99(3).

Kuciński K. (2004), Migracje w teorii ekonomii, „International Journal of Management and Economics", nr 15.

McDonald J.F. (2007), William Alonso, Richard Muth, Resources for the Future, and the Founding of Urban Economics, „Journal of the History of Economic Thought”, $\mathrm{nr} 29(1)$.

Lucas R. (1993), Making a Miracle, „Econometrica”, nr 61, [za:] Feldman M.P., Location and Innovation: The New Economic Geography of Innovation, Spillover, and Agglomeration, [w:] G.L. Clark, M.P. Feldman, M.S. Gertler (red.) (2000), Oxford Handbook of Economic Geography, Oxford University Press.

Lösch A. (1940), Die räumliche Ordnung der Wirtschaft. Eine Untersuchung über Standort, Wirtschaftsgebiete und internationalem Handel, Fischer, Jena.

McCann Ph. (2001), Urban and Regional Economics, Oxford University Press, Oxford.

McCann B.T., Folta T.B. (2008), Location Matters: Where We Have Been and Where We Might Go in Agglomeration Research, „Journal of Management”, nr 34(3), June.

Myrdal G. (1957), Economic Theory and Underdeveloped Regions, Gerald Duckworth, London.

O'Sullivan A. (2007), Urban Economics, McGraw Hill-Irwin, New York.

Ostrom E. (1990), Governing the Commons. The Evolution of Institutions for Collective Action, Cambridge University Press, New York.

Perroux F. (1955), La notion de pôle de croissance, „Économie Appliquée”, nr 8.

Pietrzyk I. (2001), Polityka regionalna Unii Europejskiej i regiony w państwach członkowskich, Wydawnictwo Naukowe PWN, Warszawa.

Pike A., Rodríguez-Pose A., Tomaney J. (2006), Local and Regional Development, Routledge, London-New York.

Polko A. (2005), Miejski rynek mieszkaniowy i efekty sąsiedztwa, Wydawnictwo Akademii Ekonomicznej w Katowicach, Katowice.

Regulski J. (1982), Ekonomika miasta, Państwowe Wydawnictwo Ekonomiczne, Warszawa.

Rodríguez-Pose A. (2010), Do Institutions Matter for Regional Development?, Working papers series in Economics and Social Sciences Ciencias Sociales IMDEA 2010/02.

Sokołowicz M.E. (2015), Rozwój terytorialny w świetle dorobku ekonomii instytucjonalnej. Przestrzeń - bliskość - instytucje, Wydawnictwo Uniwersytetu Łódzkiego, Łódź.

Storper M., Manville M. (2006), Behaviour, Preferences and Cities: Urban Theory and Urban Resurgence, „Urban Studies”, $\mathrm{nr}$ 43(8).

Thünen von J. (1826), Der isolierte Staat in Beziehung auf Landwirtschaft und Nationalekonomie, Perthes, Hamburg.

Tscharaktschiew S., Hirte G. (2010), How does the household structure shape the urban economy?, „Regional Science and Urban Economics”, nr 40(6). 
Varian H.R. (2001), Mikroekonomia, Wydawnictwo Naukowe PWN, Warszawa.

Weber A. (1909), Über den Standort der Industrie. Reine Theorie des Standorts, Tübingen.

Zasina J. (2016), The emergence of households and urbanization patterns in Poland, „DATUTOP”, nr 34.

Zaucha J. (2010a), Ekonomiczna teoria lokalizacji, [w:] P. Lorens, J. Martyniuk-Pęczek (red.), Miasto, metropolia, region. Zarządzanie rozwojem przestrzennym miast, Wydawnictwo Urbanista, Gdańsk.

Zaucha J. (2010b), Ułomności rynku, czyli dlaczego i kiedy potrzebna jest interwencja władzy publicznej, [w:] P. Lorens, J. Martyniuk-Pęczek (red.), Miasto, metropolia, region. Zarządzanie rozwojem przestrzennym miast, Wydawnictwo Urbanista, Gdańsk. 


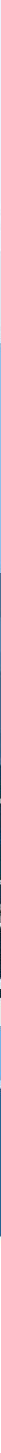

